\title{
Can Auditor Expertise Contribute to Positive Contagion?
}

\section{Yu-Shan (Stefanie) Chang, Ph.D.}

Associate Professor of Accounting

College of Business and Management

Tamkang University

No. 151, Yingzhuan Road

Danshui District, New Taipei City 25137 Taiwan (ROC)

Tel.: +886-2-2621-5656 Ext. 3370

Email: ysc@mail.tku.edu.tw

Fan-Hua (Alex) Kung, Ph.D.

Associate Professor and Chair of Accounting

College of Business and Management

Tamkang University

No. 151, Yingzhuan Road

Danshui District, New Taipei City 25137 Taiwan (ROC)

Tel.: +886-2-2621-5656 Ext. 2118

kung@mail.tku.edu.tw

\section{Magdalene Neptune, MBA}

Department of Accounting

Tamkang University

No.151, Yingzhuan Road

Danshui District, New Taipei City 25137 Taiwan (ROC)

maggie.neptune@hotmail.com

\section{* Dana A. Forgione, Ph.D., CPA, CMA, CFE}

Endowed Chair of the Jessie Francis Neal Foundation \&

Clifton W. Coonrod Endowment, and Professor of Accounting

College of Business

Texas A\&M University Corpus Christi

6300 Ocean Drive

Corpus Christi, TX 78412 USA

Tel.: +1.954.599.8141

Email: dana.forgione@tamucc.edu

* Corresponding author.

Working Draft: Please do not quote without permission.

July 23,2020 


\title{
Can Auditor Expertise Contribute to Positive Contagion?
}

\begin{abstract}
We examine the positive contagion effect of specialist auditors in reducing earnings management across industries. To our knowledge, this study is the first to provide evidence of positive contagion in the auditing literature. We examine whether an auditor with expertise in one industry can transfer their expert knowledge and skills to another industry, and thus affect the client's level of earnings management. We find that specialists can use their auditing expertise to reduce accrual-based earnings management, even when auditing outside their scope of industry expertise. We find that auditors who are specialists in particular industries are better than nonspecialists at constraining accrual-based earnings management, even for clients where neither auditor is a specialist in the client's industry. With longer auditor tenure, the positive contagion of auditor expertise is moderated. Lower-quality auditors improve as their tenure grows, tending to close the gap in audit quality.
\end{abstract}

Keywords: Contagion effect; Accrual earnings management; Real earnings management; Industry specialist; Auditor tenure.

\section{JEL Classifications: M41, M42}

Data Availability: Data are available from the public sources cited in the text. 


\section{Can Auditor Expertise Contribute to Positive Contagion?}

\section{Introduction}

Much research has provided evidence on how behavior spreads through social interactions. The contagion effect has been studied in a variety of academic fields, such as psychology, sociology, and economics, as well as in business fields, including accounting. Although contagion is a well-known and researched phenomenon, it has received little attention in accounting. Gleason, Jenkins and Johnson (2008) define contagion as occurring "when an adverse event at one firm conveys negative information about ... other firms". A few studies in accounting have contributed to the literature on contagion (Gleason et al., 2008; Chiu, Teoh, \& Tian, 2012; Francis \& Michas, 2013; Li, Qi, Tian, \& Zhang, 2016). These studies have all examined the negative effect of contagion. Francis et al. (2013) and Li et al. (2017) both examined the contagion effect of lowquality audits. While prior studies in auditing have focused solely on negative contagion, a few studies in different fields (such as marketing and psychology) have explored positive contagion (Argo, Dahl, \& Morales, 2008; Lee, Linkenauger, Bakdash, Joy-Gaba, \& Proffitt, 2011). Our study aims to determine the nature and extent of positive contagion in the auditing field.

In short, we examine whether industry specialists auditors can transfer their expertise across industries. Prior studies suggest that auditors of higher quality can constrain the level of accrual earnings management (Johnson, Khurana, \& Reynolds, 2002; Myers, Myers, \& Omer, 2003; Chi, Lisic, \& Pevzner, 2011). We argue that industry specialist auditors can transfer their expertise across industries to reduce the extent of earnings management. To manipulate earnings, two techniques are commonly recognized in earnings management: accrual-based earnings management, and real earnings management. Consequently, we expect that auditor expertise is associated with lower levels of accrual earnings management beyond the industries of their 
expertise. Past research suggests that managers switch to real earnings management when a highquality auditor constrains their use of accrual-based earnings management. In addition, they mention that real activities are harder to detect than accrual activities.

We consider positive contagion to exist if an industry specialist auditor can reduce the level of accrual earnings management for client audits performed outside their industry of specialization. As a consequence, we expect the level of real earnings management will increase, due to client management switching to real activities.

Past researchers have suggested that while firms engaging in income-smoothing practices may reap some benefits, there are costs associated with the practice. In subsequent years, managers are forced to confront the consequences of having managed previous years' earnings. Previous studies have documented that high-quality auditors are associated with high earnings quality. High-quality auditors are able to restrict managers' use of accrual-based earnings management (Johnson et al., 2002; Myers et al., 2003; Chi et al., 2011). Industry experts, due to their high audit quality, are more prone to detect inconsistent accounting practices and misrepresentations by management than low-quality auditors. Once high-quality auditors restrict managers' use of accrual earning management, managers may switch to real earnings management (Ewert and Wagenhofer, 2005; Cohen, Dey, \& Lys, 2008; Chi et al., 2011). Although the future costs of using real activities to manipulate earnings are high, the fact that it is less likely to be detected by auditors gives managers the opportunity to achieve their current earnings benchmarks. Consequently, auditor expertise can be associated with lower levels of accrual earnings management but with higher levels of real earnings management. We use the level of an auditor's industry expertise as a measure of audit quality. 
It is argued that auditor tenure and audit quality are associated, but the findings of the association are mixed. On the one hand, some researchers argue that longer auditor tenure is associated with higher audit quality, which constrains managers' use of accrual-based earnings management (Johnson et al., 2002; Myers et al., 2003; Chi et al., 2011). On the other hand, Gul, Fung and Jaggi (2009) argue that the relationship between audit quality and auditor tenure is weaker for auditor expertise. They suggest that industry specialists do not require tenure to improve their audit quality. We investigate whether auditor tenure moderates the positive contagion of auditor expertise.

Our study's sample comprises 17,877 firm-year observations from 2000 to 2016 of publicly traded companies in Taiwan. Our results show that industry specialists do use their knowledge and skills to influence the level of earnings management outside their industry of expertise. That is, auditor expertise is associated with lower levels of accrual earnings management, regardless of the industry of specialization.

Consistent with prior literature, we found that industry specialists are associated with overall lower levels of absolute discretionary accruals and income-decreasing adjustments. However, we also found that high quality auditor experts from other industries are significantly associated with lower accrual earnings management as well. Taken altogether, our findings are consistent with our prediction that industry specialists can use their expertise across industries and negatively affect the level of accrual earnings management. In addition, we also found that with longer auditor tenure, the positive contagion of auditor expertise is moderated. One possible explanation for this is that with longer auditor tenure, non-specialists may improve their audit quality. As a result, the gap in the difference in audit quality between specialist and non-specialist auditors is reduced. 
Our paper contributes to the literature by being the first research on positive contagion in auditing. Past auditing research focused exclusively on negative contagion. Our paper suggests that auditor industry specialization can constrain the level of accrual-based earnings management in different industries. Furthermore, our findings add to existing literature on the association between auditor tenure and audit quality. We add a new dimension, contagion, to this relationship. Our results suggest that with longer auditor tenure, the level of contagion becomes less significant.

The remainder of the paper proceeds as follows. The second section provides the literature review and development of our hypotheses. The third section presents the methodology, variable definitions, research models and research design. The fourth section reports the empirical results and additional analyses. We offer conclusions in the fifth section.

\section{Literature review and hypotheses development}

\subsection{Auditor expertise}

Many studies have explored auditor expertise and its influence on audit quality, but few have examined the positive contagion of auditor expertise across industries. Bédard and Chi (1993) define audit expertise as the possession of a large body of knowledge and procedural skills. They believe that expertise is task specific and consists of three components: technical knowledge, problem solving, and decision quality. First, technical knowledge is a prerequisite to expertise. Technical knowledge refers to the ability of auditors to understand accounting and audit standards and their related regulations and rules, and implement them efficiently and effectively to audit activities and audit work (Tan \& Libby, 1997). Problem solving is the ability of auditors to identify obstacles and problems of audit activities, reduce these obstacles and problems through audit management, and gain goal achievement of audit practices. To be successful in problem solving, 
auditors have implemented three dimensions to achieve higher audit quality, including problem representation, problem-solving strategies and information search (Bédard \& Chi, 1993). Problem representation refers to an auditor's interpretation and understanding of the problem. Problemsolving strategies include working forward, working backward, generate-and-test, and sub-goaling. Information search is the ability to distinguish between relevant and irrelevant information and to make more inferences from the relevant information. It can be inferred that problem solving is positively related to auditors improving their effectiveness. Bédard and Chi's (1993) final component of expertise is decision quality. It refers to an auditor's ability to choose, select, consider, and judge audit procedures and strategies in order to improve audit quality and enhance audit effectiveness. Thus, auditors can perform tasks more quickly and produce more accurate solutions. Decision quality is evaluated by three measures: consistency with professional standards, consistency with the firm's standards, and consensus among auditors (Bédard, 1989). In short, experts with superior knowledge and strategies are better able to make the best decisions.

Prior studies have examined the association between audit quality and earnings quality. A considerable number of studies have documented an association between the measures of highquality auditors (industry expertise) and high-quality financial reporting (Johnson et al., 2002; Krishnan, 2003; Balsam, Krishnan, \& Yang, 2003; Ghosh \& Moon, 2005). These studies argue that high-quality auditors are more likely to detect inconsistent accounting practices and misrepresentations by management than low-quality auditors. In an attempt to avoid being given qualified audit reports, managers may choose to address the concerns of the auditors. This will result in managers reporting financial information of higher quality, which increases earnings quality. 
Many studies have also examined the positive relationship between auditor tenure and earnings quality. They suggest that auditors with longer tenure are associated with higher earnings quality. Johnson et al. (2002) investigate the relation between audit firm tenure and absolute discretionary accruals. They classify audit firm tenure into three categories: short ( $2-3$ years), medium ( $4-8$ years), and long ( 9 or more years). They find that short audit tenure is associated with larger absolute discretionary accruals, but long tenure is not. Myers et al. (2003) extended the study of Johnson et al. (2002) by including an additional measure of accrual, i.e. current accruals. They find that the magnitude of both measures of accruals declines with longer auditor tenure. They suggest that earnings management becomes more limited as audit firm tenure grows longer.

Gul et al. (2009) examined the effect of auditor industry expertise on the association between auditor tenure and earnings quality. They limited their sample to include only firms audited by the Big 4, since these firms identify their industry-specialized auditors. Gul et al. (2009) provide evidence that auditors' industry specialization affects the relationship between auditor tenure and earnings quality. Specifically, they show that the association between shorter auditor tenure and lower earnings quality mentioned by previous studies (e.g., Johnson et al., 2002) is weaker for firms audited by industry specialists. According to Gul et al. (2009), a possible explanation for this result is that auditors with industry expertise do not need tenure, i.e., auditors with industry expertise in the client's business are more likely to detect misrepresentations and provide high-quality audits despite having limited, specific knowledge of the client in a short-term relationship. 


\subsection{Transfer of expertise}

Much research argues that expertise cannot be transferred, that is, there is no contagion of expertise. Bédard and Chi (1993) argued that one of the characteristics of expertise is that it is task specific. They believe that there is very little transfer from high-level proficiency in one domain to proficiency in other domains. Voss, Greene, Post and Penner's (1983) study of problem-solving skill in the social sciences supports this assumption. In their study, they compared the problemsolving behavior among expert chemists, expert political scientists, and novice political scientists, in solving real-world problems related to Soviet agriculture. They found that the chemists' protocols were very much like those of the novices: simple, and directed at low-level specific problems that were sub-problems for the experts. Patel and Groen (1991) made the same conclusion. Based on their study on biomedical knowledge and clinical reasoning, they found that when presented with solving a problem in the domain of cardiology, the diagnoses of general surgeons and psychiatrists were less accurate than those of cardiologists.

The above studies all focused on the transfer of experts' skill across unrelated professional domains in addressing a single problem. The question that needs to be examined is whether there is a transfer of knowledge among experts in related domains when addressing different problems. For instance, can auditors transfer their auditing expertise from one industry to another industry? Although the structure of each industry might be different, according to Bédard and Chi (1993), all auditors need to acquire broad technical knowledge in order to become experts. This knowledge involves the understanding of accounting and auditing standards that apply to all industries. Certain recognizable accounting issues may arise in different manifestations in various industries. Expert auditors can use their knowledge for all industries and quickly recognize and adapt to the 
specific characteristics of one industry; thus, the transfer of an auditor's industrial expertise is plausible.

\subsection{Earnings management}

Healy and Wahlen (1999) defined earnings management as managers using judgement in financial reporting and in structuring transactions to alter financial reports to either influence contractual outcomes that depend on reported accounting numbers, or to mislead some stakeholders about the underlying economic performance of the company. The primary objective of firms is to generate a return (usually in the form of profits) to their shareholders or stakeholders by exploiting the assets that were acquired by debt and equity capital. In order to raise capital, firms need to provide shareholders with incentives to invest. As a result, firms that fall short of reaching the desired earnings benchmarks on their own might be inclined to manage earnings to meet shareholders' expectations. The extant literature on earnings management has discussed two ways by which managers can intervene in the reporting process and manipulate earnings. A number of studies discuss that earnings can be manipulated by adjusting accruals (Jones, 1991; Dechow, Sloan, \& Sweeney, 1995; Kothari, Leone, \& Wasley, 2005). Other studies have showed that managerial intervention is not limited to only the manipulation of accruals but can be also be done through operational decisions (Dechow \& Skinner, 2000; Graham, Harvey \& Rajgopal, 2005, Cohen et al., 2008).

\subsubsection{Accrual-based earnings management}

The accrual principle states that firms should record accounting transactions in the period in which they actually occur, rather than the period in which the related cash flows take place. 
Although accruals are meant to accurately depict a firm's performance, they can be used to manage reported earnings. Managers may adjust discretionary accruals in an effort to increase reported earnings. While a number of papers have documented evidence of earnings management activities, a great number of those studies have focused on accrual-based earnings management. Early studies developed discretionary accrual models to test earnings management (e.g. Healy, 1985; DeAngelo, 1986; Jones, 1991; and Dechow et al., 1995). The two most popular models for estimating the discretionary component of accruals are the Jones (1991) model and modified-Jones model (Dechow et al., 1995). The Jones (1991) model is based on a linear regression whereby changes in sales as well as that of property, plant and equipment are regressed on total accruals. She separates total accruals into discretionary and non-discretionary accruals and uses discretionary accruals as a measure of earnings management. The main assumptions with the Jones model are that the companies do not engage in earnings management or experience any major structural changes during the model estimation period. The model makes the assumption that revenues are non-discretionary accruals and that non-discretionary accruals are constant. The results of Jones (1991) failed to explain the variation in total accruals since the study focused only on discretionary accruals and didn't examine whether changes in sales figures resulted from nondiscretionary accruals. In an attempt to eliminate the tendency of the Jones Model to categorize revenues as nondiscretionary, a modified version of the model was designed by Dechow et al. (1995). The modified model was designed to measure the error of discretionary accruals when discretion is applied to sales. When changes in receivables are adjusted to reflect changes in sales, the standard Jones model becomes a modified-Jones model.

Previous studies examined the specification and power of discretionary accrual models, but not that of performance-matched accrual models (Dechow et al., 1995). According to Dechow et al. (1995), "all models reject the null hypothesis of no earnings management at rates exceeding 
the specified test levels when applied to samples of firms with extreme financial performance." Discretionary accruals behave differently under the performance measure. Previous research (Jones, 1991; Dechow et al., 1995) did not control for a firm's performance in their model. Kothari et al. (2005) designed a performance-matched discretionary accrual measure to demonstrate that in testing for earnings management, it is crucial to take into account a firm's performance. Performance matching is on the basis of return on assets for the past year, and industry criteria. Kothari et al. (2005) matched each firm-year of a particular company to that of another company in the same industry that had the closest net income scaled by total assets in the previous year. They proposed two modifications to the original Jones model to control for performance. The first was to add either contemporaneous or lagging ROA as an explanatory variable to the Jones model. The other was to adjust the discretionary accruals for a company with the discretionary accruals for a performance-matched company. They first tested the ability of these modified models to generate mean-zero estimates when applied to stratified random samples. They concluded that the Jones and modified Jones models were unspecified for their stratified random samples. Their second test was to assess the ability of the models to detect artificially induced negative and positive earnings management. The results showed no model being superior in detecting the simulated earnings management.

\subsubsection{Real earnings management}

Roychowdhury (2006) defines real activities manipulation as "departures from normal operational practices, motivated by management's desire to mislead at least some stakeholders into believing that certain financial reporting goals have been met in the normal course of operations." Firms can choose to deviate from either operating, investing, or financing activities. Prior studies found that firms engage in real activities manipulations by cutting down on research and development (R\&D) expenditures. Dechow and Sloan (1991) found that when approaching the end of their tenure, CEOs reduce research and development (R\&D) expenditures to increase shortterm earnings. Bens, Nagar and Wong (2002) pointed out that managers repurchase stock to avoid earnings per share (EPS) dilution and partially finance these repurchases by reducing R\&D. 
In addition to reduction of $R \& D$ expenditures, managers can engage in a range of activities that deviate from normal operating and investing activities. Roychowdhury's (2006) study, based on all firms in COMPUSTAT from the post-1986 period to 2001, examined how firms close to a zero-earnings benchmark avoided losses. The study examined the patterns in those firms' cash flow from operations (CFO), discretionary expenses and production costs, and found that firms overproduced to report lower cost of goods sold (COGS), provided price discounts toward the end of the year to temporarily increase sales volumes, and reduced discretionary expenses to lower reported expenses, and thus increase earnings.

Recent studies provide evidence that firms tend to favor using real activities over accrualbased manipulations, despite the costs associated with real activity manipulations. Although real activity manipulation increases a current period's earnings, it has an adverse effect on a firm's future value (Cohen \& Zarowin, 2010). For example, current year overproduction results in excess inventory that must be sold in future years, which imposes greater holding costs on the firm. Reductions in $\mathrm{R} \& \mathrm{D}$ expenditures result in less innovation, which can make the company less competitive in the future. Notwithstanding the negative effects of real earnings management, managers prefer it to accrual management, because it is harder to identify by auditors and regulators. Auditors and regulators are more able to scrutinize accrual earnings management and thus restrain its use. The Graham et al. (2005) survey of more than 400 executives provided strong evidence that managers engage in real activities to maintain accounting appearances. The study reveals that $80 \%$ of the executives interviewed admit they would decrease $R \& D$ expenses, advertising, and maintenance to meet a short-term earnings target. This evidence suggests that managers prefer real earnings management activities compared with accrual-based earnings management. This is because real earnings management activities are less likely to be scrutinized 
by auditors and regulators, and thus have a lower probability of being detected, even though the long-term negative consequences of such activities can be economically significant to the firm.

Cohen et al. (2008) studied the level of real and accrual-based earnings management in the pre- and post-Sarbanes Oxley (SOX) periods. They examined abnormal levels of cash flow from operations (CFO), discretionary expenses, and production costs. Cohen et al. (2008) focused on three manipulation methods and their impact on three variables: (1) acceleration of the timing of sales through increased price discounts or more lenient credit terms, (2) reporting of lower cost of goods sold through increased production, and (3) decreases in discretionary expenses such as advertising expense, R\&D, and selling, general and administrative expenses (SG\&A). Consistent with the conjectures made by Graham et al. (2005) and Cohen et al. (2008), they found evidence that managers switched from accrual-based to real earnings management in the post-SOX period. This evidence indicates that in the post-SOX period after many highly publicized accounting scandals during the economic upheaval of 1998, the desire to avoid detection of accrual-based earnings management is greater than previous periods, which evidently motivated managers to switch from accrual-based to real based earnings management.

Chi et al. (2011) investigated whether higher audit quality is associated with increased use of real earnings management. The study found that auditors with higher audit quality restrained management's use of accruals, which led managers to shift to using real earnings management. Chi et al. (2011) point out that firms with strong upward earnings management incentives (firms that meet or just beat earnings benchmarks, and firms that issue seasoned equities) are associated with higher levels of real earnings management.

Based on the above inferences, we developed two hypotheses. The first hypothesis considers that industry specialists can transfer their knowledge and skills to other industries, and 
therefore affect the level of earnings management. If either or both levels of accrual-based earnings management and real earnings management are reduced, then positive contagion has occurred. The second hypothesis considers that with longer auditor tenure, auditors may improve their audit quality. As a result, auditors are more able to detect inconsistencies and misrepresentations. We expect that auditor tenure will be associated with positive contagion. Our hypotheses are formulated as follows:

H1: Ceteris paribus, an industry specialist auditor is negatively associated with the level of earnings management by firms outside their industry of specialization (positive contagion)

H2: Auditor tenure moderates the significance of the positive contagion.

\section{Research methodology}

\subsection{Discretionary accruals}

In this study, we follow prior literature in using discretionary accruals as a proxy variable to measure accruals-based earnings management. In the past, the Jones (1991) model and the Modified Jones Model (Dechow et al., 1995) have both been used extensively in the research on discretionary accruals. To test our hypothesis, we adopt Kothari et al.'s (2005) performance-based modification of the Jones (1991) model as follows:

$$
\begin{aligned}
& T A_{i, t} / \operatorname{Assets}_{i, t-1}=\beta_{0}+\beta_{1}\left(1 / \operatorname{Assets}_{i, t-1}\right)+\beta_{2}\left(\Delta R E V_{i, t}-\Delta R E C_{i, t} / \text { Assets }_{i, t-1}\right)+ \\
& \beta_{3}\left(P P E_{i, t} / \text { Assets }_{i, t-1}\right)+\beta_{4} R O A_{i, t-1}+\varepsilon_{i, t} \\
& \left.D A_{i, t}=T A_{i, t} / \text { Assets }_{i, t-1}\right)-\left\{b_{0}+b_{1}\left(1 / \text { Assets }_{i, t-1}\right)+b_{2}\left(\Delta R E V_{i, t}-\Delta R E C_{i, t} / A_{\operatorname{Assts}_{i, t-1}}\right)+\right. \\
& \left.b_{3}\left(P P E_{i, t} / \operatorname{Assets}_{i, t-1}\right)+b_{4}\left(R O A_{i, t-1}\right)\right\}+\varepsilon_{i, t}
\end{aligned}
$$

where: 
$T A_{i, t}=$ total accruals for year $t$ measured as income from continuing operations less operating cash flow;

Assets $_{i, t-1}=$ total assets;

$\triangle R E V_{i, t}=$ change in revenue for year $t$

$\Delta R E C_{i, t}=$ change in accounts receivable for year $t$

$P P E_{i, t} \quad=$ net property, plant and equipment for year $t$;

$R O A_{i, t-1}=$ return on asset for year $t-1$ (net income divided by total assets);

$\varepsilon_{i, t} \quad=\quad$ error terms.

We ran the following model to measure the level of earnings management through discretionary accruals. We take the absolute value of discretionary accruals $(A B S D A)$, positive value of discretionary accruals $\left(D A^{+}\right)$and the negative value of discretionary accruals $\left(D A^{-}\right)$.

$$
\begin{aligned}
& A B S D A_{t}\left(D A^{+}{ }_{t} \text { or } D A^{-}{ }_{t}\right)=\alpha_{0}+\alpha_{1} S P E C L S T_{-} A_{i, t}+\alpha_{2} S P E C L S T_{-} B_{i, t}+ \\
& \alpha_{3} S P E C L S T_{-} A * T E N U R E_{i, t}+\alpha_{4} S P E C L S T \_B * T E N U R E_{i, t}+\alpha_{5} S I Z E_{i, t}+\alpha_{6} G R O W T H_{i, t}+ \\
& \alpha_{7} \mathrm{CFO}_{i, t}+\alpha_{8} \mathrm{TENURE}_{i, t}+\alpha_{9} A G E_{i, t}+\alpha_{10} R_{-} E M_{i, t}+\alpha_{11} B I G N_{i, t}+\Sigma Y E A R_{i, t}+ \\
& \sum \operatorname{INDUSTR} Y_{i, t}+\varepsilon_{i, t}
\end{aligned}
$$

where:

ABSDA = absolute discretionary accruals;

$D A^{+} \quad=\quad$ positive discretionary accruals

$D A^{-} \quad$ negative discretionary accruals;

SPECSLT_A $=1$ if the auditor is a specialist in Industry A as well as an auditor in

Industry B, else 0;

SPECSLT_B $=1$ if the auditor is a specialist in Industry B and audits only firms from

Industry B, else 0; 


\begin{tabular}{|c|c|c|}
\hline TENURE & $=$ & number of consecutive years the firm has retained the auditor; \\
\hline$S I Z E$ & $=$ & natural logarithm of total assets at beginning of year; \\
\hline GROWTH & $=$ & $\begin{array}{l}\text { firm's growth rate calculated as current year's net sales minus previous } \\
\text { year's net sales, divided by previous year's net sales; }\end{array}$ \\
\hline CFO & $=$ & cash flow from operations divided by previous year's total assets; \\
\hline$A G E$ & $=$ & number of years of establishment of each firm; \\
\hline$R \_E M$ & $=$ & $\begin{array}{l}\text { sum of the standardized three real earnings management proxies, i.e., } \\
\text { abnormal cash flow }\left(R_{-} C F O\right) \text {, abnormal production costs }\left(R_{-} P R O D\right) \text {, and } \\
\text { abnormal discretionary expenses }\left(R_{-} D I S X\right) \text {, following Cohen } \text { et al. }(2008) \text {; }\end{array}$ \\
\hline$B I G N$ & $=$ & 1 if the auditor belongs to a large accounting firm, else 0 ; \\
\hline$Y E A R$ & $=$ & dummy variable for calendar year; \\
\hline$V D U$ & & dummy variable for industry. \\
\hline
\end{tabular}

If an auditor industry specialist uses his expertise to constrain the use of accrual-based earnings management, by managers outside his industry of specialization, we expect the coefficient on SPECLST_A to be negative when we use $A B S D A$ as the dependent variable. We also expect the coefficient on SPECLST_A to be negative for positive discretionary accruals $\left(D A^{+}\right)$and positive for negative discretionary accruals $\left(D A^{-}\right)$.

The literature on the association between auditor tenure and audit quality is quite mixed. It is argued that longer auditor tenure can either improve or impair audit quality. In our regression, we control for auditor TENURE. We expect the longer tenure to moderate the significance of positive contagion. That is, as non-specialists increase their tenure, their audit quality may also increase. Thus, the gap in audit quality between specialist and non-specialist auditors would be 
reduced. We also control for other salient variables from prior literature, and for fixed year and industry effects.

\subsection{Real earnings management}

Following Cohen et al. (2008), we consider abnormally low levels of cash flow from operations and discretionary expenses, and abnormally high levels of production costs as indicators of upward real activities manipulations. Our estimation of abnormal cash flow $\left(R \_C F O\right)$, abnormal production costs $\left(R \_P R O D\right)$, and abnormal discretionary expenses $\left(R \_D I S X\right)$ are used as proxies for real earnings management. First, we estimate the normal CFO for each industry and year by using the regression Model (4)

$$
\begin{gathered}
\text { CFO }_{i, t} / \text { Assets }_{i, t-1}=a_{1 t}\left(1 / \text { Assets }_{i, t-1}\right)+a_{2 t}\left(\text { Sales }_{i, t} / \text { Assets }_{i, t-1}\right)+ \\
a_{3 t}\left(\Delta \text { Sales }_{i, t} / \text { Assets }_{i, t-1}\right)+\varepsilon_{i, t}
\end{gathered}
$$

where $C F O=$ cash flow from operations. Similarly, we use Model (5) to estimate the normal level of production costs:

$\operatorname{Prod}_{i, t} / \operatorname{Assets}_{i, t-1}=b_{1 t}\left(1 /\right.$ Assets $\left._{i, t-1}\right)+b_{2 t}\left(\right.$ Sales $_{i, t} /$ Assets $\left._{i, t-1}\right)+b_{3 t}\left(\Delta\right.$ Sales $_{i, t} /$ Assets $\left._{i, t-1}\right)+$

$$
b_{4 t}\left(\Delta \text { Sales }_{i, t-1} / \operatorname{Assets}_{i, t-1}\right)+\varepsilon_{i, t}
$$

where $\operatorname{Prod}=$ sum of cost of goods sold and change in inventory in year $t$. Finally, we estimate the normal level of discretionary expenses using Model (6):

$\operatorname{Disx}_{i, t} /$ Assets $_{i, t-1}=c_{1}\left(1 /\right.$ Assets $\left._{i, t-1}\right)+c_{2}\left(\right.$ Sales $_{i, t-1} /$ Assets $\left._{i, t-1}\right)+\varepsilon_{i, t}$

where Disx $=$ sum of advertising expenses, R\&D expenses, and SG\&A expenses. The abnormal CFO $\left(R \_C F O\right)$, abnormal production costs $\left(R \_P R O D\right)$ and abnormal discretionary expenses $\left(R \_D I S X\right)$ are calculated as the residuals of regression models (4), (5) and (6); i.e. the actual values minus the estimated normal levels calculated using these models. 
Also, following Cohen et al. (2008), we develop a comprehensive measure of real earnings management by combining the three individual variables into a single variable. Specifically, we multiply $R_{-} C F O$ and $R_{-} D I S X$ each by negative one. We interpret higher amounts of standardized $R_{-} C F O$ and $R_{-} D I S X$ as indicating greater possibility that a firm is engaging in manipulations through price discounts and cutting discretionary expenses. We do not multiply $R_{-} P R O D$ by negative one since, as previously discussed, higher production costs indicate overproduction to reduce cost of goods sold, and thus increase income. Therefore, our new combined measure, REM is the sum of the three standardized individual variables, i.e. $R E M=-R_{-} C F O+R_{-} P R O D-$ R_DISX.

To test our hypothesis, we run the following regression model.

$R_{-} E M_{t}, \quad\left(R_{-} C F O_{t}\right.$ or $R_{-} P R O D_{t}$ or $\left.R_{-} D I S X_{t}\right)=\gamma_{0}+\gamma_{1} S P E C L S T_{-} A_{t}+\gamma_{2} S P E C L S T_{-} B_{t}+$

$$
\begin{aligned}
& \gamma_{3} S P E C L S T \_A * T E N U R E_{t}+\gamma_{4} S P E C L S T \_B * T E N U R E_{t}+\gamma_{5} L E V_{t}+\gamma_{6} L N M A R_{t}+\gamma_{7} M T B_{t} \\
& +\gamma_{8} \Delta E_{t}+\gamma_{9} R O A_{t}+\gamma_{10} A B S D A_{t}+\gamma_{11} B I G N_{t}+\Sigma Y E A R+\Sigma I N D U S T R Y+\varepsilon_{t}
\end{aligned}
$$

where:

$R_{-} E M \quad=\quad$ sum of the standardized three real earnings management proxies, i.e., $R \_C F O, R_{-} P R O D$ and $R \_D I S X$;

$R_{-} C F O=$ level of abnormal cash flows from operations;

$R_{-} P R O D=\quad$ level of abnormal production costs, where production costs are defined as the sum of cost of goods sold and the change in inventories;

$R_{-} D I S X=$ level of abnormal discretionary expenses, where discretionary expenses are the sum of advertising expenses, R\&D expenses and SG\&A expenses;

SPECSLT_A $=1$ if auditor is a specialist in Industry A as well as an auditor in Industry B, else 0 ; 
SPECSLT_B $=1$ if auditor is a specialist in Industry B and audits only firms from Industry B, else 0 ;

TENURE $=$ number of consecutive years the firm has retained the auditor;

LEV $\quad=$ total debt as a percentage of total assets;

LNMAR $=$ natural log of market value of equity for a firm;

MTB $\quad=$ firm's market-to-book ratio;

$\Delta \mathrm{E} \quad=\quad$ change in firm's annual earnings, deflated by prior year assets;

ROA $=$ ratio of earnings before extraordinary items deflated by prior period assets;

$A B S D A=$ absolute discretionary accruals;

$B I G N=1$ if auditor belongs to a large accounting firm, else $0 ;$

YEAR $=$ dummy variable for calendar year;

INDUSTRY $=$ dummy variable for industry.

\subsection{Sample selection and data descriptions}

This study includes all of the publicly listed firms in Taiwan during 2000-2016. However, we excluded the financial and insurance industries from the sample due to their unique structures. We obtain all financial and auditing data used for computing our dependent and independent variables from the Taiwan Economic Journal (TEJ). We omit all firms with incomplete variable data. Our final sample consists of 17,877 firm-year observations. In order to address problems caused by small denominators and to control for the effect of potential outliers and extreme values, we Winsorize the top and bottom $1 \%$ of the distribution. Table 1 presents our sample selection. The Electronic components industry is the largest contributor to our sample (13.4\%), followed by the Semiconductor industry (8.1\%) and the Computer and peripherals industry (7.1\%). 
[Please Place Table 1 About Here]

Table 2 describes the statistics and univariate test results. Panel A presents the descriptive statistics for all variables in our regression models. It can be observed from the table that the absolute value of discretionary accruals $(A B S D A)$ has a mean of 0.064 and median of 0.044 . The composite index for real earnings management $\left(R_{-} E M\right)$ has a mean (median) of $0.003(0.066)$, where the three components, $R_{-} C F O, R_{-} P R O D$ and $R_{-} D I S X$ have means (medians) of 0.009 (0.011), $-0.012(-0.007)$ and $0.013(0.004)$, respectively. Panel B of Table 2 highlights the differences in values for all variables between auditor specialists from two different industries (SPECLST_A, SPECLST_B). From the table, we observe that the level of absolute discretionary accruals for SPECLST_A (0.063) is lower than that of SPECLSTB (0.074). The mean value of discretionary accruals $(D A)$ for $S P E C L S T \_B(-0.046)$ is significantly lower than SPECLST_A (0.001). This difference is significant at the $1 \%$ level. The difference in the mean values for the composite index of real earnings management $\left(R_{-} E M\right)$ did not reach a significant level. The mean of real earnings management measure $R_{-} C F O$ for $S P E C L S T \_B(0.046)$ is significantly higher than the mean of SPECLST_A (0.010). The average value for auditor tenure (TENURE) is significantly lower for SPECLST_A at the $1 \%$ level.

[Please Place Table 2 About Here]

Panel $\mathrm{C}$ of Table 2 reports the differences in values for all variables between auditor specialists (SPECLST_A), and NONSPECLST (an indicator variable for non-specialist auditor). We observe that the mean (median) absolute value of discretionary accruals for SPECLST_A and 
NONSPECLST are $0.063(0.043)$ and $0.065(0.044)$, respectively. The average level of abnormal discretionary expenses for NONSPECLST (0.014) is significantly higher than SPECLST_A (0.010).

Table 3 presents both Pearson and Spearman correlation coefficients between our variables. $R_{-} E M$ is positively correlated with $A B S D A . R_{-} C F O, R_{-} P R O D$ and $R_{-} D I S X$ are negatively, positively and negatively correlated with $A B S D A$, respectively. SPECLST_A is negatively correlated with $A B S D A$ while NONSPECLST is positively correlated with ABSDA. There is a strong negative correlation between TENURE and ABSDA. There is also a strong negative correlation between $R_{-} P R O D$ and $R_{-} D I S X$ which implies that managers use the two measures as substitutes. These correlations suggest that, overall, auditor industry specialists and tenure are correlated with lower levels of accrual earnings management.

[Please Place Table 3 About Here]

\section{Empirical results}

Tables 4 and 5 present the main results of our study. The first objective of our paper is to determine whether an auditor industry expert is negatively associated with the level of earnings management outside their industry of expertise. We refer to this as positive contagion. The second part of our study aims to determine whether the positive contagion is moderated as auditor tenure grows.

\subsection{Auditor industry expertise and accrual earnings management}

Table 4 reports the regression results when we use the absolute value of discretionary accruals $(A B S D A)$, positive discretionary accruals $\left(D A^{+}\right)$, and negative discretionary accruals $\left(D A^{-}\right)$as our dependent variables. We find a negative and significant coefficient of $-0.004(p \leq 0.023)$ and a 
positive and significant coefficient of $0.006(p \leq 0.017)$ on SPECLST_A in the absolute value of discretionary accruals $(A B S D A)$ and the negative discretionary accruals $\left(D A^{-}\right)$regressions, respectively. This suggests that auditor industry specialist constrains managers' use of accrualbased earnings management not only in his industry of expertise, but also in other industries. However, when the interaction variable for industry specialist and auditor tenure (SPECLST_A $*$ TENURE) is observed, it can be seen that the aforementioned results are reversed. There is a positive and significant coefficient of $0.001(p \leq 0.043)$ and a negative and significant coefficient of $-0.001(p \leq 0.011)$ on SPECLST_A $*$ TENURE in the ABSDA and $D A^{-}$regressions. This provides evidence that with tenure the contagion effect of auditor expertise across industries is lessen. SPECLST_B has a positive and significant coefficient of $0.041(p \leq 0.025)$ in the ABSDA regression which indicates that, overall, clients engage in accrual-based earnings management. There is a negative and significant coefficient of $-0.038(p \leq 0.049)$ on SPECLST_B in the $D A^{-}$ regression indicating that clients of this auditor engage in income-decreasing adjustments. The interaction variable $S P E C L S T \_B * T E N U R E$, has a negative and significant coefficient of -0.003 ( $p \leq 0.012)$ in the $A B S D A$ regression. Furthermore, the coefficient of auditor tenure (TENURE) is negative and significant on the $A B S D A$ regression and positive and significant on the $D A^{-}$ regression. Consistent with prior studies, these results indicate that auditors improve their audit quality with longer tenure.

[Please Place Table 4 About Here]

\subsection{Auditor industry expertise and real earnings management}

Table 5 reports the regression results when we use the composite index for real earnings management $\left(R_{-} E M\right)$, and its components abnormal cash flow $\left(R_{-} C F O\right)$, abnormal production 
costs $\left(R_{-} P R O D\right)$, and abnormal discretionary expenses $\left(R_{-} D I S X\right)$ as dependent variables. We find a positive and significant coefficient of $0.127(p \leq 0.065)$ on SPECLST_A in the $R \_E M$ regression, suggesting that auditor industry expertise is associated with more overall real earnings management. We find a negative and significant coefficient of $-0.009(p \leq 0.013)$ on SPECLST_A in the $R_{-} D I S X$ regression. This suggests that higher auditor industry expertise is associated with lower discretionary expenses. Overall, these results suggest that auditor industry expertise is affiliated with more real earnings management due to the restriction high quality auditors place on the use of accrual earnings management. There is a positive and significant coefficient of 0.079 ( $p$ $\leq 0.000)$ on $S P E C L S T \_B$ in the $R_{-} C F O$ regression, indicating that auditor industry expertise is associated with constrained use of abnormal cash flow as a real activity. However, the interaction term SPECLST_B * TENURE has a negative and significant coefficient of $-0.004(p \leq 0.000)$ in the $R_{-} C F O$ regression. This suggests that as tenure grows, an auditor's ability to detect CFO activities is moderated. That is, high quality auditors with longer tenure results in higher abnormal cash flows. Our results on the effect of auditor tenure (TENURE) on the level of real earnings management did not reach a significant level.

[Please Place Table 5 About Here]

\subsection{Additional analyses}

We perform some additional tests to further validate whether the positive contagion effect of industry specialist auditors on reducing the extent of earnings management across industries exists. We divided our sample into subgroups based on auditor expertise or audit quality, and use regressions (3) and (7) with the same variable definitions.

$A B S D A_{t}\left(D A^{+}{ }_{t}\right.$ or $\left.D A^{-}{ }_{t}\right)=\alpha_{0}+\alpha_{1} S P E C L S T_{-} A_{i, t}+\alpha_{2} S P E C L S T_{-} B_{i, t}+$ 


$$
\begin{aligned}
& \alpha_{3} S P E C L S T \_A * T E N U R E_{i, t}+\alpha_{4} S P E C L S T \_B * T E N U R E_{i, t}+\alpha_{5} S I Z E_{i, t}+\alpha_{6} G R O W T H_{i, t}+ \\
& \alpha_{7} \mathrm{CFO}_{i, t}+\alpha_{8} \operatorname{TENURE}_{i, t}+\alpha_{9} A G E_{i, t}+\alpha_{10} R_{-} E M_{i, t}+\alpha_{11} B I G N_{i, t}+\Sigma Y E A R_{i, t}+ \\
& \sum \operatorname{INDUSTR} Y_{i, t}+\varepsilon_{i, t}
\end{aligned}
$$

$R_{-} E M_{t}, \quad\left(R_{-} C F O_{t}\right.$ or $R_{-} P R O D_{t}$ or $\left.R_{-} D I S X_{t}\right)=\gamma_{0}+\gamma_{1} S P E C L S T \_A_{t}+\gamma_{2} S P E C L S T \_B_{t}+$

$$
\begin{aligned}
& \gamma_{3} S P E C L S T_{-} A * T E N U R E_{t}+\gamma_{4} S P E C L S T_{-} B * T E N U R E_{t}+\gamma_{5} L E V_{t}+\gamma_{6} L N M A R_{t}+\gamma_{7} M T B_{t} \\
& +\gamma_{8} \Delta E_{t}+\gamma_{9} R O A_{t}+\gamma_{10} A B S D A_{t}+\gamma_{11} B I G N_{t}+\Sigma Y E A R+\Sigma I N D U S T R Y+\varepsilon_{t}
\end{aligned}
$$

We then define the additional variables:

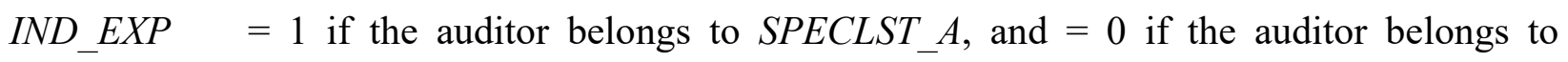
SPECLST_B (and the interaction term IND_EXP * TENURE, for auditor industry specialist and auditor tenure)

$A U D=1$ if the auditor is a specialist, else 0 (and the interaction term $A U D * T E N U R E$, for auditor quality and auditor tenure.

We describe our additional tests below.

\subsubsection{Auditor industry expertise and earnings management}

Prior studies suggest that high-quality auditors are more likely to detect inconsistent accounting practices and misrepresentations by management than low-quality auditors. Therefore, we use $I N D_{-} E X P$ to compare the measures of auditor expertise (SPECLST_A and SPECLST_B) and examine the behavior of our model's variables. We report the results in Tables 6 and 7 .

Table 6 presents the results of the regression for auditor industry specialists with the measures of accrual earnings management as dependent variables. We expect the coefficient on $A B S D A$ and $D A^{-}$, to be negative and positive, respectively. Consistent with our expectations, we find a negative and significant coefficient of $-0.047(p \leq 0.015)$ on $I N D \_E X P$ in the $A B S D A$ regression. This suggests, overall, that $S P E C L S T \_A$ is better at constraining the use of accrual- 
based earnings management than SPECLST_B. In addition, the coefficient of IND_EXP in the $D A^{-}$ regression is positive and significant, $0.041(p \leq 0.019)$. This also suggests that auditor expertise is associated with lower income-decreasing adjustments. There is a positive and significant coefficient of $0.004(p \leq 0.008)$ on IND_EXP * TENURE in the ABSDA regression. This result suggests that with longer tenure SPECLST_B's audit quality improved. As a result, the gap in the audit quality of the two industry specialists (SPECLST_A and SPECLST_B) is reduced.

[Please Place Table 6 About Here]

Table 7 presents the results of the regression for auditor industry specialists with the measures of real earnings management as dependent variables. The coefficient of IND_EXP has a negative and significant coefficient of $-0.069(p \leq 0.000)$ in the $R_{-} C F O$ regression, which suggests that higher audit quality is associated with higher abnormal cash flows. There is a positive and significant coefficient of $0.003(p \leq 0.019)$ on $I N D_{-} E X P * T E N U R E$ in the $R_{-} C F O$ regression. This result suggests that auditor expertise together with longer auditor tenure results in lower abnormal cash flows. Furthermore, the coefficient of auditor tenure (TENURE) in the R_CFO regression is negative and significant of $-0.003(p \leq 0.019)$. These results support the findings of Gul et al. (2009) that auditor industry specialists do not need tenure. The findings of our study suggest that longer tenure helps auditor industry specialists detect real activity earnings management.

[Please Place Table 7 About Here] 


\subsubsection{Auditor industry specialist vs non-specialist and earnings management}

In an effort to better understand the relationship between auditor expertise and the level of earnings management, we perform additional tests combining auditor industry specialist (SPECLST_A) with non-specialists to observe their association with earnings management. Our findings are presented in Tables 8 and 9. Table 8 reports the regression results using the measures of accrual-based earnings management as dependent variables. From the table, we observe that the coefficient of $A U D$ is negative and significant, $-0.004(p \leq 0.023)$ in the $A B S D A$ regression. This suggests that, overall, SPECLST_A is associated with lower levels of accrual earnings management. That is, consistent with prior studies, high quality auditors can better detect inconsistencies than non-specialists. The interaction term, $A U D * T E N U R E$, has a positive and significant coefficient of 0.001 ( $p \leq 0.044$ ) in the ABSDA regression, and a negative and significant coefficient, -0.001 $(p \leq 0.011)$ in the $D A^{-}$regression. These results suggest that non-specialists improve their audit quality with longer tenure.

Table 9 presents our regression results using the measures of real earnings management as the dependent variables. We find no significant data to show that auditor expertise negatively affects the level of real earnings management. The coefficient of $A U D$ in the $R_{-} E M$ regression is positive and significant, $0.128(p \leq 0.064)$ and the coefficient of $A U D$ in the $R \_D I S X$ regression is negative and significant, $-0.009(p \leq 0.013)$. These results suggest that once high-quality auditors constrain managers' use of accrual-based earnings management, they switch to real earnings management which is less likely to be detected.

[Please Place Tables 8 and 9 About Here] 


\section{Conclusion}

We examine whether auditor industry specialists can transfer their expertise to industries outside their scope of expertise, and thus affect the level of earnings management. The literature on audit quality and earnings quality suggests that higher audit quality constrains accrual earnings management. Our proxy for audit quality is auditor industry specialist. We find a negative association between absolute discretionary accruals and auditor industry specialists, suggesting that overall, industry specialists do constrain the level of accrual-based earnings management. We further find that the positive association between auditor industry specialist and negative discretionary accruals is significant. These findings suggest that an auditor can transfer their industry expertise to other industries and negatively affect the level of accrual-based earnings management. Thus, this supports our hypothesis that auditor expertise can generate a positive contagion effect on earnings management. An industry specialist's knowledge and expertise are not limited to only their area of expertise. The findings support the literature that suggests higher audit quality constrains accrual earnings management. We add to the literature by demonstrating that the negative association between audit quality and earnings management holds even for industry specialists who audit firms outside their specialization.

It has been debated that longer auditor tenure is associated with lower accrual earnings management. Our results suggest that auditor tenure moderates the contagion observed. Specifically, the longer the tenure among specialists of other industries, the higher the quality of their audits, which in turn reduces the magnitude of the gap in audit quality between an industry specialist and a specialist of other industries.

Given that existing literature on the contagion effect in auditing has focused on the negative side, there is clear indication of a need for research focusing on positive contagion. Furthermore, 
future research need not focus only on positive contagion in auditing. Future studies can also extend to such areas as financial accounting and management accounting.

\section{REFERENCES}

Argo, J. J., Dahl, D. W., \& Morales, A. C., 2008. Positive consumer contagion: Responses to attractive others in a retail context. Journal of Marketing Research, 45(6), 690-701. DOI:10.1509/jmkr.45.6.690.

Balsam, S., Krishnan, J., \& Yang, J. S., 2003. Auditor industry specialization and earnings quality. Auditing: A Journal of Practice and Theory, 22(2), 71-97. DOI:10.2308/aud.2003.22.2.71.

Bédard, J., 1989. Expertise in auditing; Myth or reality. Accounting Organizations and Society, 14(1-2), 113-131. DOI:10.1016/0361-3682(89)90037-8.

Bédard, J., \& Chi, M. T., 1993. Expertise in auditing; Discussion. Auditing: A Journal of Practice \& Theory, 12, 21-45. DOI:10.2308/aud.2003.22.1.195.

Bens, D. A., Nagar, V., \& Wong, M. F., 2002. Real investment implications of employee stock option exercises. Journal of Accounting Research, 40(2), 359-393. DOI:10.1111/1475679X.00053.

Chi, W., Lisic, L. L., \& Pevzner, M., 2011. Is enhanced audit quality associated with greater real earnings management? Accounting Horizons, 25(2), 315-335. DOI:10.2308/acch-10025.

Chiu, P. C., Teoh, S. H., \& Tian, F., 2012. Board interlocks and earnings management contagion. The Accounting Review, 88(3), 915-944. DOI:10.2308/accr-50369.

Cohen, D. A., Dey, A., \& Lys, T. Z., 2008. Real and accrual-based earnings management in the pre- and post-Sarbanes-Oxley periods. The Accounting Review, 83(3), 757-787. DOI:10.2308/accr.2008.83.3.757. 
Cohen, D. A., \& Zarowin, P., 2010. Accrual-based and real earnings management activities around seasoned equity offerings. Journal of Accounting and Economics, 50(1), 2-19. DOI:10.1016/j.jacceco.2010.01.002.

DeAngelo, L. E., 1986. Accounting numbers as market valuation substitutes: A study of management buyouts of public stockholders. The Accounting Review, 61(3), 400-420. DOI:10.1177/1032373218779188.

Dechow, P. M., Sloan, R. G., \& Sweeney, A. P., 1995. Detecting earnings management. The Accounting Review, 70, 193-225. DOI:10.1111/j.1475-679X.2012.00449.x.

Dechow, P. M., \& Sloan, R. G., 1991. Executive incentives and the horizon problem: An empirical investigation. Journal of Accounting and Economics, 14(1), 51-89. DOI:10.1016/01677187(91)90058-S.

Dechow, P. M., \& Skinner, D. J., 2000. Earnings management: Reconciling the views of accounting academics, practitioners, and regulators. Accounting Horizons, 14(2), 235-250. DOI:10.2308/acch.2000.14.2.235.

Ewert, R., \& Wagenhofer, A., 2005. Economic effects of tightening accounting standards to restrict earnings management. The Accounting Review, 80(4), 1101-1124. DOI:10.2308/accr.2005.80.4.1101.

Francis, J. R., \& Michas, P. N., 2012. The contagion effect of low-quality audits. The Accounting Review, 88(2), 521-552. DOI:10.2308/accr-50322.

Ghosh, A., \& Moon, D., 2005. Auditor tenure and perceptions of audit quality. The Accounting Review, 80(2), 585-612. DOI:10.2308/accr.2005.80.2.585.

Gleason, C. A., Jenkins, N. T., \& Johnson, W. B., 2008. The contagion effects of accounting restatements. The Accounting Review, 83(1), 83-110. DOI:10.2308/accr.2008.83.1.83. 
Gow, I. D., Ormazabal, G., \& Taylor, D. J., 2010. Correcting for cross-sectional and time-series dependence in accounting research. The Accounting Review, 85(2), 483-512. DOI:10.2308/accr.2010.85.2.483.

Graham, J. R., Harvey, C. R., \& Rajgopal, S., 2005. The economic implications of corporate financial reporting. Journal of Accounting and Economics, 40(1-3), 3-73. DOI:10.1016/j.jacceco.2005.01.002.

Gul, F. A., Fung, S. Y. K., \& Jaggi, B., 2009. Earnings quality: Some evidence on the role of auditor tenure and auditors' industry expertise. Journal of Accounting and Economics, 47(3), 265-287. DOI:10.1016/j.jacceco.2009.03.001.

Healy, P. M., 1985. The effect of bonus schemes on accounting decisions. Journal of Accounting and Economics, 7(1-3), 85-107. DOI:10.1016/0165-4101(85)90030-8.

Healy, P. M., \& Wahlen, J. M., 1999. A review of the earnings management literature and its implications for standard setting. Accounting Horizons, 13(4), 365-383. DOI:10.2308/acch.1999.13.4.365.

Johnson, V. E., Khurana, I. K., \& Reynolds, J. K., 2002. Audit-firm tenure and the quality of financial reports. Contemporary Accounting Research, 19(4), 637-660. DOI:10.1506/LLTH-JXQV-8CEW-8MXD.

Jones, J. J., 1991. Earnings management during import relief investigations. Journal of Accounting Research, 29(2), 193-228. DOI:10.2307/2491047.

Krishnan, G. V., 2003. Does Big 6 auditor industry expertise constrain earnings management? Accounting Horizons, 17, 1-16. DOI:10.2308/acch.2003.17.s-1.1. 
Kothari, S. P., Leone, A. J., \& Wasley, C. E., 2005. Performance matched discretionary accrual measures. Journal of Accounting and Economics, 39(1), 163-197. DOI:10.1016/j.jacceco.2004.11.002.

Lee, C., Linkenauger, S. A., Bakdash, J. Z., Joy-Gaba, J. A., \& Profitt, D. R., 2011. Putting like a pro: The role of positive contagion in golf performance and perception. PLoS One, 6(10), e26016. DOI:10.1371/journal.pone.0026016.

Li, L., Qi, B., Tian, G., \& Zhang, G., 2016. The contagion effect of low-quality audits at the level of individual auditors. The Accounting Review, 92(1), 137-163. DOI:10.2308/accr-51407.

Libby, R., \& Luft, J., 1993. Determinants of judgment performance in accounting settings: Ability, knowledge, motivation, and environment. Accounting, Organizations and Society, 18(5), 425-450. DOI:10.1016/0361-3682(93)90040-D.

Myers, J. N., Myers, L. A., \& Omer, T. C., 2003. Exploring the term of the auditor-client relationship and the quality of earnings: A case for mandatory auditor rotation? The Accounting Review, 78(3), 779-799. DOI:10.2308/accr.2003.78.3.779.

Petersen, M. A., 2009. Estimating standard errors in finance panel data sets: Comparing approaches. The Review of Financial Studies, 22(1), 435-480. DOI:10.1093/rfs/hhn053.

Patel, V. L., \& Groen, G. J., 1991. The general and specific nature of medical expertise: A critical look. Toward a General Theory of Expertise: Prospects and Limits, 93-125. DOI:10.1057/9780230523470_2.

Roychowdhury, S., 2006. Earnings management through real activities manipulation. Journal of Accounting and Economics, 42(3), 335-370. DOI:10.1016/j.jacceco.2006.01.002. 
Tan, H. T., \& Libby, R., 1997. Tacit managerial versus technical knowledge as determinants of audit expertise in the field. Journal of Accounting Research, 35(1), 97-113. DOI:10.2307/2491469.

Voss, J. F., Greene, T. R., Post, T. A., \& Penner, B. C., 1983. Problem-solving skill in the social sciences. The Psychology of Learning and Motivation, 17, 165-213. DOI:10.1016/S00797421(08)60099-7. 
Table 1

Sample Distribution

\begin{tabular}{|c|c|c|c|c|c|c|c|c|c|c|c|c|c|c|c|c|c|c|c|}
\hline Industry & 2000 & 2001 & 2002 & 2003 & 2004 & 2005 & 2006 & 2007 & 2008 & 2009 & 2010 & 2011 & 2012 & 2013 & 2014 & 2015 & 2016 & Total & $\%$ \\
\hline Cement & 7 & 7 & 7 & 7 & 7 & 7 & 7 & 7 & 7 & 7 & 7 & 7 & 7 & 7 & 7 & 7 & 7 & 119 & $0.7 \%$ \\
\hline Food and drink & 22 & 23 & 22 & 23 & 24 & 24 & 24 & 24 & 24 & 24 & 24 & 24 & 25 & 26 & 26 & 26 & 27 & 412 & $2.3 \%$ \\
\hline Plastic & 19 & 22 & 22 & 22 & 22 & 24 & 24 & 24 & 24 & 24 & 24 & 24 & 25 & 26 & 26 & 27 & 27 & 406 & $2.3 \%$ \\
\hline Textile & 46 & 47 & 49 & 50 & 51 & 51 & 50 & 52 & 52 & 51 & 52 & 52 & 53 & 53 & 54 & 55 & 55 & 873 & $4.8 \%$ \\
\hline Electric Machinery & 29 & 35 & 39 & 42 & 47 & 52 & 56 & 58 & 60 & 61 & 63 & 64 & 67 & 72 & 76 & 82 & 89 & 992 & $5.6 \%$ \\
\hline Electrical and Cable & 12 & 13 & 13 & 13 & 13 & 13 & 13 & 13 & 13 & 13 & 13 & 14 & 15 & 15 & 16 & 16 & 16 & 234 & $1.3 \%$ \\
\hline Paper & 7 & 7 & 7 & 7 & 7 & 7 & 7 & 7 & 7 & 7 & 7 & 7 & 7 & 7 & 7 & 7 & 7 & 119 & $0.7 \%$ \\
\hline Iron and Steel & 27 & 30 & 32 & 33 & 34 & 33 & 34 & 37 & 37 & 39 & 39 & 40 & 40 & 39 & 40 & 42 & 42 & 618 & $3.5 \%$ \\
\hline Rubber & 9 & 9 & 10 & 10 & 10 & 10 & 10 & 11 & 11 & 11 & 11 & 11 & 11 & 11 & 12 & 12 & 12 & 181 & $1.0 \%$ \\
\hline Automobile & 4 & 4 & 4 & 4 & 4 & 5 & 5 & 5 & 5 & 5 & 5 & 5 & 5 & 6 & 6 & 6 & 6 & 84 & $0.5 \%$ \\
\hline Construction & 44 & 49 & 51 & 57 & 61 & 63 & 64 & 64 & 65 & 63 & 67 & 68 & 67 & 68 & 68 & 68 & 68 & 1,055 & $5.9 \%$ \\
\hline Shipping & 17 & 17 & 19 & 19 & 19 & 19 & 19 & 19 & 19 & 20 & 21 & 22 & 22 & 22 & 23 & 25 & 25 & 347 & $1.9 \%$ \\
\hline Tourism & 11 & 12 & 13 & 13 & 14 & 15 & 15 & 15 & 15 & 15 & 15 & 16 & 17 & 23 & 26 & 27 & 30 & 292 & $1.6 \%$ \\
\hline Consumer Goods & 14 & 14 & 14 & 17 & 19 & 22 & 23 & 23 & 23 & 23 & 23 & 23 & 25 & 28 & 29 & 30 & 31 & 381 & $2.1 \%$ \\
\hline Others & 34 & 39 & 47 & 55 & 57 & 60 & 62 & 62 & 64 & 66 & 66 & 67 & 76 & 80 & 84 & 87 & 93 & 1,099 & $6.2 \%$ \\
\hline Chemical & 23 & 27 & 30 & 29 & 29 & 32 & 33 & 33 & 34 & 34 & 35 & 35 & 37 & 37 & 38 & 38 & 39 & 563 & $3.2 \%$ \\
\hline Biotechnology & 5 & 7 & 11 & 15 & 21 & 29 & 32 & 33 & 34 & 36 & 40 & 45 & 56 & 68 & 82 & 84 & 89 & 687 & $3.8 \%$ \\
\hline Energy & 8 & 10 & 11 & 11 & 12 & 12 & 12 & 12 & 12 & 12 & 12 & 12 & 12 & 12 & 12 & 12 & 12 & 196 & $1.1 \%$ \\
\hline Semiconductor & 28 & 34 & 44 & 53 & 62 & 73 & 78 & 83 & 93 & 96 & 100 & 104 & 112 & 115 & 120 & 126 & 135 & 1,456 & $8.1 \%$ \\
\hline Comp. \& peripherals & 27 & 35 & 41 & 52 & 63 & 68 & 73 & 76 & 84 & 84 & 89 & 91 & 93 & 95 & 100 & 102 & 103 & 1,276 & $7.1 \%$ \\
\hline Photoelectric & 13 & 20 & 26 & 40 & 47 & 54 & 59 & 66 & 73 & 79 & 84 & 93 & 103 & 109 & 113 & 118 & 121 & 1,218 & $6.8 \%$ \\
\hline Communic. network & 11 & 15 & 23 & 35 & 43 & 46 & 51 & 56 & 56 & 59 & 61 & 64 & 71 & 73 & 78 & 80 & 87 & 909 & $5.1 \%$ \\
\hline Electronic components & 39 & 53 & 68 & 94 & 109 & 120 & 138 & 143 & 154 & 158 & 168 & 174 & 184 & 188 & 195 & 200 & 203 & 2,388 & $13.4 \%$ \\
\hline $\begin{array}{l}\text { Electronics } \\
\text { distribution }\end{array}$ & 4 & 9 & 12 & 17 & 22 & 30 & 32 & 33 & 34 & 35 & 35 & 35 & 36 & 35 & 35 & 35 & 35 & 474 & $2.7 \%$ \\
\hline Information service & 6 & 12 & 14 & 19 & 24 & 26 & 27 & 28 & 28 & 29 & 29 & 29 & 30 & 32 & 32 & 33 & 35 & 433 & $2.4 \%$ \\
\hline Other electronics & 16 & 20 & 24 & 34 & 38 & 45 & 50 & 51 & 58 & 59 & 63 & 66 & 69 & 70 & 71 & 73 & 75 & 882 & $4.9 \%$ \\
\hline Cultural and creative & 1 & 1 & 3 & 6 & 8 & 10 & 10 & 11 & 11 & 12 & 12 & 12 & 14 & 15 & 18 & 19 & 20 & 183 & $1.0 \%$ \\
\hline Total & 483 & 571 & 656 & 777 & 867 & 950 & 1,008 & 1,046 & 1,097 & 1,122 & 1,165 & 1,204 & 1,279 & 1,332 & 1,394 & 1,437 & 1,489 & 17,877 & $\begin{array}{c}100.0 \\
\%\end{array}$ \\
\hline
\end{tabular}


Table 2

Descriptive Statistics

Panel A: Distribution of All Variables in Full Sample $(n=17,877)$

\begin{tabular}{lrrrrrrr}
\hline \multicolumn{1}{c}{ Variable } & Mean & \multicolumn{1}{c}{ S.D. } & \multicolumn{1}{c}{ Min. } & \multicolumn{1}{c}{ Q1 } & Median & \multicolumn{1}{c}{ Q3 } & \multicolumn{1}{c}{ Max. } \\
\hline$A B S D A$ & 0.064 & 0.067 & 0.000 & 0.020 & 0.044 & 0.084 & 0.366 \\
$D A$ & 0.000 & 0.093 & -0.321 & -0.045 & -0.001 & 0.043 & 0.366 \\
$R \_E M$ & 0.003 & 1.644 & -7.983 & -0.784 & 0.066 & 0.828 & 7.588 \\
$R \_C F O$ & 0.009 & 0.108 & -0.452 & -0.043 & 0.011 & 0.065 & 0.393 \\
$R \_P R O D$ & -0.012 & 0.129 & -0.466 & -0.074 & -0.007 & 0.051 & 0.432 \\
$R \_D I S X$ & 0.013 & 0.085 & -0.263 & -0.027 & 0.004 & 0.044 & 0.386 \\
SPECLST_A & 0.278 & 0.448 & 0.000 & 0.000 & 0.000 & 1.000 & 1.000 \\
SPECLST_B & 0.002 & 0.050 & 0.000 & 0.000 & 0.000 & 0.000 & 1.000 \\
NONSPECLST & 0.720 & 0.449 & 0.000 & 0.000 & 1.000 & 1.000 & 1.000 \\
SIZE & 22.237 & 1.396 & 19.123 & 21.254 & 22.048 & 23.011 & 26.333 \\
GROWTH & 0.096 & 0.509 & -0.618 & -0.093 & 0.035 & 0.175 & 6.016 \\
CFO & 0.066 & 0.114 & -0.457 & 0.011 & 0.065 & 0.126 & 0.492 \\
TENURE & 6.998 & 4.120 & 1.000 & 4.000 & 6.000 & 9.000 & 18.000 \\
$A G E$ & 27.281 & 12.413 & 3.000 & 18.000 & 26.000 & 36.000 & 58.000 \\
LEV & 0.420 & 0.175 & 0.068 & 0.288 & 0.422 & 0.542 & 0.894 \\
$L N M A R$ & 21.828 & 1.430 & 19.041 & 20.812 & 21.676 & 22.664 & 26.178 \\
MTB & 1.586 & 1.230 & 0.295 & 0.815 & 1.222 & 1.912 & 7.923 \\
$\triangle E$ & 0.008 & 0.074 & -0.209 & -0.024 & 0.003 & 0.031 & 0.355 \\
$R O A$ & 0.044 & 0.096 & -0.283 & 0.003 & 0.040 & 0.088 & 0.472 \\
BIGN & 0.838 & 0.369 & 0.000 & 1.000 & 1.000 & 1.000 & 1.000 \\
\hline
\end{tabular}


Panel B: SPECLST_A $(n=4,967)$ vs. SPECLST_B $(n=44)^{1}$

\begin{tabular}{|c|c|c|c|c|c|c|}
\hline Variable & Mean & S.D. & Q1 & Median & Q3 & t-value \\
\hline \multicolumn{7}{|l|}{$A B S D A$} \\
\hline SPECLST_A & 0.063 & 0.066 & 0.018 & 0.043 & 0.082 & \multirow[t]{2}{*}{1.16} \\
\hline SPECLST_B & 0.074 & 0.072 & 0.024 & -0.032 & 0.101 & \\
\hline \multicolumn{7}{|l|}{$D A$} \\
\hline SPECLST $A$ & 0.001 & 0.091 & -0.044 & -0.001 & 0.042 & \multirow[t]{2}{*}{$-3.38^{* * *}$} \\
\hline$S P E C L S T-B$ & -0.046 & 0.093 & -0.100 & -0.032 & 0.021 & \\
\hline \multicolumn{7}{|l|}{$R \_E M$} \\
\hline $\bar{S} P E C L S T \_A$ & 0.028 & 1.608 & -0.764 & 0.064 & 0.843 & \multirow[t]{2}{*}{-0.54} \\
\hline$S P E C L S T \_B$ & -0.102 & 1.183 & -0.881 & -0.050 & 0.558 & \\
\hline \multicolumn{7}{|l|}{$R C F O$} \\
\hline $\bar{S} P E C L S T \_A$ & 0.010 & 0.105 & -0.042 & 0.012 & 0.065 & \multirow[t]{2}{*}{$2.30^{* *}$} \\
\hline SPECLST_B & 0.046 & 0.093 & -0.017 & 0.037 & 0.108 & \\
\hline \multicolumn{7}{|l|}{$R_{P} P R O D$} \\
\hline $\bar{S} P E C L S T \_A$ & -0.011 & 0.126 & -0.073 & -0.007 & 0.051 & \multirow[t]{2}{*}{-0.27} \\
\hline SPECLST_B $B$ & -0.016 & 0.094 & -0.065 & -0.014 & 0.023 & \\
\hline \multicolumn{7}{|l|}{$R \_D I S X$} \\
\hline $\bar{S} P E C L S T \_A$ & 0.010 & 0.084 & -0.029 & 0.002 & 0.042 & \multirow[t]{2}{*}{-1.12} \\
\hline$S P E C L S T \_B$ & -0.005 & 0.059 & -0.022 & -0.002 & 0.012 & \\
\hline \multicolumn{7}{|l|}{ SIZE } \\
\hline SPECLST_A & 22.295 & 1.431 & 21.258 & 22.070 & 23.106 & \multirow[t]{2}{*}{$2.83^{* *}$} \\
\hline SPECLST_B $B$ & 22.908 & 1.418 & 21.676 & 22.983 & 23.956 & \\
\hline \multicolumn{7}{|l|}{ GROWTH } \\
\hline SPECLST_A & 0.092 & 0.467 & -0.086 & 0.038 & 0.177 & \multirow[t]{2}{*}{-1.11} \\
\hline SPECLST_B & 0.014 & 0.258 & -0.139 & 0.051 & 0.145 & \\
\hline \multicolumn{7}{|l|}{$\mathrm{CFO}$} \\
\hline SPECLST_A & 0.067 & 0.110 & 0.011 & 0.067 & 0.126 & \multirow[t]{2}{*}{0.55} \\
\hline$S P E C L S T \_B$ & 0.076 & 0.102 & 0.004 & 0.049 & 0.146 & \\
\hline \multicolumn{7}{|l|}{ TENURE } \\
\hline SPECLST_A & 7.093 & 4.115 & 4.000 & 7.000 & 10.000 & \multirow[t]{2}{*}{$3.77^{* * *}$} \\
\hline SPECLST_B & 9.455 & 5.955 & 4.000 & 9.500 & 15.500 & \\
\hline$A G E$ & & & & & & \\
\hline SPECLST_A & 27.468 & 12.619 & 18.000 & 26.000 & 36.000 & $2.48^{* *}$ \\
\hline SPECLST_B & 32.205 & 13.218 & 19.500 & 31.000 & 44.500 & \\
\hline$L E V$ & & & & & & \\
\hline$S P E C L S T \_A$ & 0.417 & 0.175 & 0.285 & 0.415 & 0.542 & 1.08 \\
\hline SPECLSTB & 0.446 & 0.146 & 0.372 & 0.454 & 0.552 & \\
\hline$L N M A R$ & & & & & & \\
\hline SPECLST_A & 21.874 & 1.443 & 20.842 & 21.694 & 22.693 & 0.78 \\
\hline SPECLST_B & 22.045 & 1.546 & 20.978 & 21.562 & 23.045 & \\
\hline$M T B$ & & & & & & \\
\hline SPECLST_A & 1.558 & 1.197 & 0.794 & 1.205 & 1.894 & $-3.39^{* * *}$ \\
\hline SPECLST_B $B$ & 0.946 & 0.614 & 0.606 & 0.791 & 1.131 & \\
\hline$\Delta E$ & & & & & & \\
\hline SPECLST_A & 0.007 & 0.073 & 0.794 & 1.205 & 1.894 & $-1.95^{* *}$ \\
\hline SPECLST_B & -0.015 & 0.067 & -0.025 & 0.002 & 0.030 & \\
\hline $\boldsymbol{R O A}$ & & & & & & \\
\hline SPECLST_A & 0.046 & 0.093 & 0.005 & 0.040 & 0.088 & $-1.62^{*}$ \\
\hline SPECLST B & 0.023 & 0.060 & 0.003 & 0.025 & 0.044 & \\
\hline BIGN & & & & & & \\
\hline SPECLST_A & 0.926 & 0.262 & 1.000 & 1.000 & 1.000 & $-11.16^{* * *}$ \\
\hline SPECLST_B & 0.477 & 0.505 & 0.000 & 0.000 & 1.000 & \\
\hline
\end{tabular}

${ }^{1}$ SPECLST_B sample size is very small due to the fact that it consists of industry specialist auditors who exclusively perform audits in Industry B. The average number of SPECLST_B auditors is about five per year. 
Panel C: SPECLST_A $(n=4,967)$ vs. NONSPECLST $(n=12,866)$

\begin{tabular}{|c|c|c|c|c|c|c|}
\hline Variable & Mean & S.D. & $Q 1$ & Median & $Q 3$ & t-value \\
\hline \multicolumn{7}{|l|}{$A B S D A$} \\
\hline SPECLST_A & 0.063 & 0.066 & 0.018 & 0.043 & 0.082 & \multirow[t]{2}{*}{$1.91^{*}$} \\
\hline NONSPEC $\bar{C} S T$ & 0.065 & 0.067 & 0.020 & 0.044 & 0.085 & \\
\hline \multicolumn{7}{|l|}{$D A$} \\
\hline SPECLST_A & 0.001 & 0.091 & -0.044 & -0.001 & 0.042 & \multirow[t]{2}{*}{-0.56} \\
\hline NONSPEC $\bar{C} S T$ & -0.000 & 0.093 & -0.046 & -0.001 & 0.043 & \\
\hline \multicolumn{7}{|l|}{ R_EM } \\
\hline $\bar{S} P E C L S T \_A$ & 0.028 & 1.608 & -0.764 & 0.064 & 0.843 & \multirow[t]{2}{*}{-1.26} \\
\hline NONSPE $\bar{C} L S T$ & -0.006 & 1.659 & -0.792 & 0.066 & 0.823 & \\
\hline \multicolumn{7}{|l|}{$R_{-} C F O$} \\
\hline $\bar{S} P E C L S T \_A$ & 0.010 & 0.105 & -0.042 & 0.012 & 0.065 & \multirow[t]{2}{*}{-0.76} \\
\hline NONSPE $\bar{C} L S T$ & 0.008 & 0.110 & -0.044 & 0.010 & 0.065 & \\
\hline \multicolumn{7}{|l|}{$R \_P R O D$} \\
\hline $\bar{S} P E C L S T \_A$ & -0.011 & 0.126 & -0.073 & -0.007 & 0.051 & \multirow[t]{2}{*}{-0.72} \\
\hline NONSPEC $\bar{C} L S T$ & -0.013 & 0.130 & -0.074 & -0.007 & 0.051 & \\
\hline \multicolumn{7}{|l|}{$R \_D I S X$} \\
\hline $\bar{S} P E C L S T \_A$ & 0.010 & 0.084 & -0.029 & 0.002 & 0.042 & \multirow[t]{2}{*}{$2.90^{* *}$} \\
\hline NONSPEC $L S T$ & 0.014 & 0.085 & -0.027 & 0.005 & 0.045 & \\
\hline \multicolumn{7}{|l|}{$S I Z E$} \\
\hline SPECLST_A & 22.295 & 1.431 & 21.258 & 22.070 & 23.106 & \multirow[t]{2}{*}{$-3.54^{* *}$} \\
\hline NONSPE $\bar{C} L S T$ & 22.212 & 1.381 & 21.251 & 22.042 & 22.964 & \\
\hline \multicolumn{7}{|l|}{ GROWTH } \\
\hline SPECLST $A$ & 0.092 & 0.467 & -0.086 & 0.038 & 0.177 & \multirow[t]{2}{*}{0.62} \\
\hline NONSPEC $\bar{C} L S T$ & 0.097 & 0.525 & -0.096 & 0.033 & 0.175 & \\
\hline \multicolumn{7}{|l|}{$\mathrm{CFO}$} \\
\hline SPECLST_A & 0.067 & 0.110 & 0.011 & 0.067 & 0.126 & \multirow[t]{2}{*}{-0.57} \\
\hline NONSPEC $L S T$ & 0.066 & 0.115 & 0.011 & 0.064 & 0.127 & \\
\hline \multicolumn{7}{|l|}{$T E N U R E$} \\
\hline SPECLST_A & 7.093 & 4.115 & 4.000 & 7.000 & 10.000 & \multirow[t]{2}{*}{$-2.04^{* *}$} \\
\hline NONSPEC $\bar{C} L S T$ & 6.953 & 4.112 & 4.000 & 6.000 & 9.000 & \\
\hline$A G E$ & & & & & & \\
\hline SPECLST_A & 27.468 & 12.619 & 18.000 & 26.000 & 36.000 & -1.34 \\
\hline NONSPEC $L S T$ & 27.191 & 12.327 & 18.000 & 26.000 & 36.000 & \\
\hline$L E V$ & & & & & & \\
\hline SPECLST_A & 0.417 & 0.175 & 0.285 & 0.415 & 0.542 & 1.14 \\
\hline NONSPECLSTT & 0.421 & 0.174 & 0.290 & 0.424 & 0.542 & \\
\hline$L N M A R$ & & & & & & \\
\hline SPECLST_A & 21.874 & 1.443 & 20.842 & 21.694 & 22.693 & $-2.66^{* *}$ \\
\hline NONSPEC $L S T$ & 21.810 & 1.424 & 20.799 & 21.666 & 22.647 & \\
\hline$M T B$ & & & & & & \\
\hline SPECLST_A & 1.558 & 1.197 & 0.794 & 1.205 & 1.894 & $1.99^{* *}$ \\
\hline NONSPEC $\bar{C} L S T$ & 1.599 & 1.244 & 0.827 & 1.233 & 1.924 & \\
\hline$\Delta E$ & & & & & & \\
\hline SPECLST_A & 0.007 & 0.073 & 0.794 & 1.205 & 1.894 & 1.15 \\
\hline NONSPEC $L S T$ & 0.008 & 0.075 & 0.008 & 0.075 & 0.008 & \\
\hline $\boldsymbol{R O A}$ & & & & & & \\
\hline SPECLST_A & 0.046 & 0.093 & 0.005 & 0.040 & 0.088 & -1.27 \\
\hline NONSPE $\bar{C} L S T$ & 0.044 & 0.097 & 0.003 & 0.040 & 0.088 & \\
\hline BIGN & & & & & & \\
\hline SPECLST_A & 0.926 & 0.262 & 1.000 & 1.000 & 1.000 & $-19.88^{* * *}$ \\
\hline NONSPECL $L S T$ & 0.805 & 0.396 & 1.000 & 1.000 & 1.000 & \\
\hline
\end{tabular}


Table 2

(continued)

Variable Definitions:

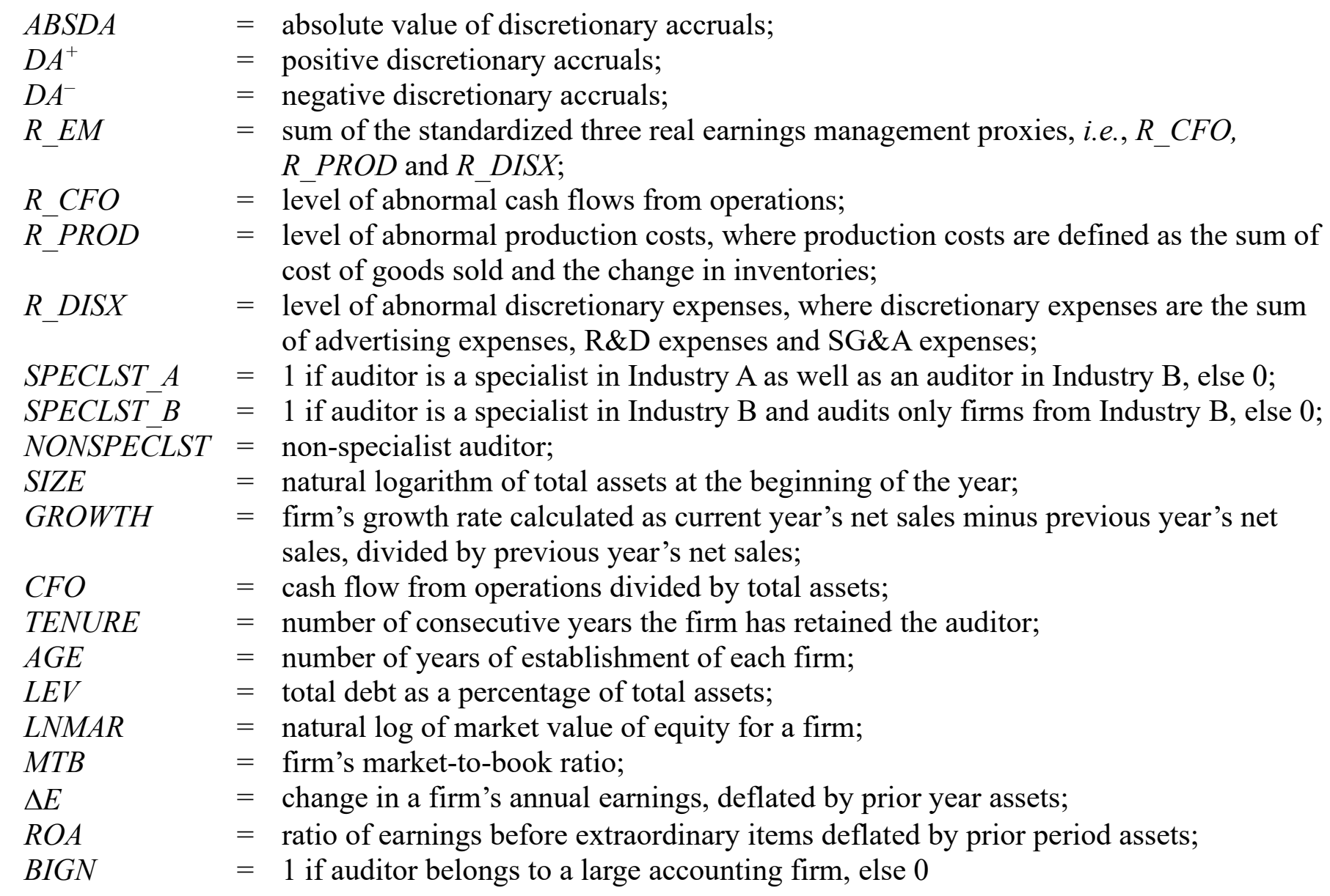


Table 3

Pearson $\backslash$ Spearman Correlation Coefficients

$(p$-value $)$
$n=17,877$

\begin{tabular}{|c|c|c|c|c|c|c|c|c|c|c|}
\hline & $A B S D A$ & $D A$ & $R \_E M$ & R_CFO & $R \_P R O D$ & $R \_D I S X$ & SPECLST_A & SPECLST_B & NONSPECLST & SIZE \\
\hline \multirow[t]{2}{*}{$A B S D A$} & 1.00 & $-0.02 * *$ & $0.06^{* * *}$ & $-0.06^{* * *}$ & $0.06^{* * *}$ & $-0.03 * * *$ & $-0.02 * *$ & 0.01 & $0.02 * *$ & $-0.11^{* * * *}$ \\
\hline & & $(0.03)$ & $(0.00)$ & $(0.00)$ & $(0.00)$ & $(0.00)$ & $(0.01)$ & $(0.33)$ & $(0.02)$ & $(0.00)$ \\
\hline \multirow[t]{2}{*}{$D A$} & $0.08^{* * *}$ & 1.00 & $0.32 * * *$ & $-0.59 * * *$ & $0.18^{* * *}$ & -0.01 & 0.00 & $-0.02 * * *$ & 0.00 & $0.02 * * *$ \\
\hline & $(0.00)$ & & $(0.00)$ & $(0.00)$ & $(0.00)$ & $(0.18)$ & $(0.82)$ & $(0.01)$ & $(0.94)$ & $(0.00)$ \\
\hline \multirow[t]{2}{*}{$R_{-} E M$} & $0.13^{* * *}$ & $0.38^{* * *}$ & 1.00 & $-0.66 * * *$ & $0.92 * * *$ & $-0.66^{* * *}$ & 0.01 & -0.01 & -0.01 & $-0.04 * * *$ \\
\hline & $(0.00)$ & $(0.00)$ & & $(0.00)$ & $(0.00)$ & $(0.00)$ & $(0.37)$ & $(0.32)$ & $(0.44)$ & $(0.00)$ \\
\hline \multirow[t]{2}{*}{$\mathrm{R}_{-} \mathrm{CFO}$} & $-0.15^{* * *}$ & $-0.64 * * *$ & $-0.70^{* * *}$ & 1.00 & $-0.54 * * *$ & $0.07 * * *$ & 0.01 & $0.02^{* *}$ & -0.01 & $0.07 * * *$ \\
\hline & $(0.00)$ & $(0.00)$ & $(0.00)$ & & $(0.00)$ & $(0.00)$ & $(0.43)$ & $(0.03)$ & $(0.30)$ & $(0.00)$ \\
\hline \multirow[t]{2}{*}{$R_{-} P R O D$} & $0.11^{* * *}$ & $0.24 * * *$ & $0.93 * * *$ & $-0.57 * * *$ & 1.00 & $-0.54 * * *$ & 0.00 & -0.01 & -0.00 & 0.00 \\
\hline & $(0.00)$ & $(0.00)$ & $(0.00)$ & $(0.00)$ & & $(0.00)$ & $(0.80)$ & $(0.44)$ & $(0.87)$ & $(0.85)$ \\
\hline \multirow[t]{2}{*}{$R_{-}$DISX } & $-0.04 * * *$ & $-0.03 * * *$ & $-0.73 * * *$ & $0.09^{* * *}$ & $-0.58^{* * *}$ & 1.00 & $-0.02 * * *$ & -0.01 & $0.02 * * *$ & $0.03^{* * *}$ \\
\hline & $(0.00)$ & $(0.00)$ & $(0.00)$ & $(0.00)$ & $(0.00)$ & & $(0.00)$ & $(0.29)$ & $(0.00)$ & $(0.00)$ \\
\hline \multirow[t]{2}{*}{ SPECLST_A } & $-0.02 *$ & 0.01 & 0.01 & 0.01 & 0.01 & $-0.02 * * *$ & 1.00 & $-0.03 * * *$ & $-0.99 * * *$ & $0.02 * *$ \\
\hline & $(0.05)$ & $(0.49)$ & $(0.20)$ & $(0.49)$ & $(0.47)$ & $(0.00)$ & & $(0.00)$ & $(0.00)$ & $(0.03)$ \\
\hline \multirow[t]{2}{*}{$S P E C L S T \_B$} & 0.01 & $-0.03 * * *$ & -0.00 & $0.02 * *$ & -0.00 & -0.01 & $-0.03 * * *$ & 1.00 & $-0.08^{* * *}$ & $0.02^{* * *}$ \\
\hline & $(0.32)$ & $(0.00)$ & $(0.67)$ & $(0.02)$ & $(0.84)$ & $(0.18)$ & $(0.00)$ & & $(0.00)$ & $(0.00)$ \\
\hline \multirow[t]{2}{*}{ NONSPECLST } & $0.01 *$ & -0.00 & -0.01 & -0.01 & -0.01 & $0.02 * * *$ & $-0.99 * * *$ & $-0.08 * * *$ & 1.00 & $-0.02 * *$ \\
\hline & $(0.07)$ & $(0.74)$ & $(0.22)$ & $(0.35)$ & $(0.48)$ & $(0.00)$ & $(0.00)$ & $(0.00)$ & & $(0.01)$ \\
\hline \multirow[t]{2}{*}{ SIZE } & $-0.13 * * *$ & $0.02^{* * *}$ & $-0.03^{* * *}$ & $0.09^{* * *}$ & $0.01 *$ & 0.01 & $0.03^{* * *}$ & $0.02^{* * * *}$ & $-0.03 * * *$ & 1.00 \\
\hline & $(0.00)$ & $(0.00)$ & $(0.00)$ & $(0.00)$ & $(0.10)$ & $(0.36)$ & $(0.00)$ & $(0.00)$ & $(0.00)$ & \\
\hline \multirow[t]{2}{*}{ GROWTH } & $0.16^{* * *}$ & $0.06^{* * *}$ & $-0.05^{* * *}$ & 0.01 & $-0.02 * *$ & $0.09 * * *$ & -0.00 & -0.01 & 0.01 & $0.03 * * *$ \\
\hline & $(0.00)$ & $(0.00)$ & $(0.00)$ & $(0.25)$ & $(0.03)$ & $(0.00)$ & $(0.56)$ & $(0.29)$ & $(0.48)$ & $(0.00)$ \\
\hline \multirow[t]{2}{*}{$\mathrm{CFO}$} & $-0.20 * * *$ & $-0.56^{* * *}$ & $-0.56^{* * *}$ & $0.84 * * *$ & $-0.46^{* * *}$ & $0.07 * * *$ & 0.00 & 0.00 & -0.01 & $0.12^{* * *}$ \\
\hline & $(0.00)$ & $(0.00)$ & $(0.00)$ & $(0.00)$ & $(0.00)$ & $(0.00)$ & $(0.58)$ & $(0.56)$ & $(0.54)$ & $(0.00)$ \\
\hline \multirow[t]{2}{*}{ TENURE } & $-0.10^{* * *}$ & 0.01 & $-0.03 * * *$ & $0.03 * * *$ & $-0.02 * * *$ & 0.01 & $0.01 *$ & $0.03 * * *$ & $-0.02 * *$ & $0.13^{* * *}$ \\
\hline & $(0.00)$ & $(0.39)$ & $(0.00)$ & $(0.00)$ & $(0.00)$ & $(0.43)$ & $(0.06)$ & $(0.00)$ & $(0.02)$ & $(0.00)$ \\
\hline \multirow[t]{2}{*}{$A G E$} & $-0.14 * * *$ & $0.02 * *$ & $0.06^{* * *}$ & $-0.04 * * *$ & $0.06^{* * *}$ & $-0.04 * * *$ & 0.01 & $0.02 * * *$ & -0.01 & $0.26^{* * *}$ \\
\hline & $(0.00)$ & $(0.01)$ & $(0.00)$ & $(0.00)$ & $(0.00)$ & $(0.00)$ & $(0.21)$ & $(0.01)$ & $(0.12)$ & $(0.00)$ \\
\hline \multirow[t]{2}{*}{$L E V$} & $0.06^{* * *}$ & $-0.02 * *$ & $0.22 * * *$ & $-0.18^{* * *}$ & $0.21 * * *$ & $-0.13 * * *$ & -0.01 & 0.01 & 0.01 & $0.28^{* * *}$ \\
\hline & $(0.00)$ & $(0.01)$ & $(0.00)$ & $(0.00)$ & $(0.00)$ & $(0.00)$ & $(0.24)$ & $(0.32)$ & $(0.29)$ & $(0.00)$ \\
\hline \multirow[t]{2}{*}{ LNMAR } & $-0.12 * * *$ & 0.00 & $-0.18^{* * *}$ & $0.20^{* * *}$ & $-0.14 * * *$ & $0.08^{* * *}$ & $0.02 * * *$ & 0.01 & $-0.02 * * *$ & $0.86^{* * *}$ \\
\hline & $(0.00)$ & $(0.57)$ & $(0.00)$ & $(0.00)$ & $(0.00)$ & $(0.00)$ & $(0.01)$ & $(0.31)$ & $(0.01)$ & $(0.00)$ \\
\hline \multirow[t]{2}{*}{ MTB } & $0.12 * * *$ & $0.02 * *$ & $-0.21 * * *$ & $0.15^{* * *}$ & $-0.23^{* * *}$ & $0.12 * * *$ & $-0.01 *$ & $-0.03 * * *$ & $0.02 * *$ & $-0.05^{* * *}$ \\
\hline & $(0.00)$ & $(0.02)$ & $(0.00)$ & $(0.00)$ & $(0.00)$ & $(0.00)$ & $(0.06)$ & $(0.00)$ & $(0.02)$ & $(0.00)$ \\
\hline \multirow[t]{2}{*}{$\Delta E$} & $0.07 * * *$ & 0.01 & $-0.03 * * *$ & $0.07 * * *$ & $-0.05^{* * *}$ & $-0.04 * * *$ & -0.01 & $-0.02 * *$ & 0.01 & -0.01 \\
\hline & $(0.00)$ & $(0.25)$ & $(0.00)$ & $(0.00)$ & $(0.00)$ & $(0.00)$ & $(0.28)$ & $(0.04)$ & $(0.19)$ & $(0.17)$ \\
\hline \multirow[t]{2}{*}{ ROA } & $-0.04 * * *$ & $0.04 * * *$ & $-0.28 * * *$ & $0.31 * * *$ & $-0.31 * * *$ & $0.05^{* * *}$ & 0.01 & -0.01 & -0.01 & $0.14^{* * *}$ \\
\hline & $(0.00)$ & $(0.00)$ & $(0.00)$ & $(0.00)$ & $(0.00)$ & $(0.00)$ & $(0.19)$ & $(0.14)$ & $(0.25)$ & $(0.00)$ \\
\hline \multirow[t]{2}{*}{$B I G N$} & $-0.05 * * *$ & $-0.02 * *$ & $-0.09 * * *$ & $0.07 * * *$ & $-0.07 * * *$ & $0.07 * * *$ & $0.15^{* * *}$ & $-0.05^{* * *}$ & $-0.14 * * *$ & $0.12^{* * *}$ \\
\hline & $(0.00)$ & $(0.01)$ & $(0.00)$ & $(0.00)$ & $(0.00)$ & $(0.00)$ & $(0.00)$ & $(0.00)$ & $(0.00)$ & $(0.00)$ \\
\hline
\end{tabular}

Notes:

a. Lower-left triangle is Pearson correlation coefficients; upper-right triangle is Spearman correlation coefficients.

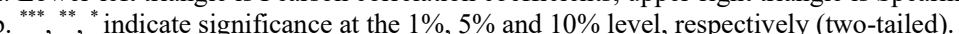

c. Variables are as defined in Table 2 . 
Table 3

Pearson $\backslash$ Spearman Correlation Coefficients

(p-value)

(continued)

\begin{tabular}{|c|c|c|c|c|c|c|c|c|c|c|}
\hline & GROWTH & CFO & TENURE & $A G E$ & $L E V$ & $L N M A R$ & MTB & $\Delta E$ & ROA & BIGN \\
\hline$A B S D A$ & $\begin{array}{l}0.04 * * * \\
(0.00)\end{array}$ & $\begin{array}{l}-0.08^{* * *} \\
(0.00)\end{array}$ & $\begin{array}{l}-0.09^{* * *} \\
(0.00)\end{array}$ & $\begin{array}{l}-0.16^{* * *} \\
(0.00)\end{array}$ & $\begin{array}{l}0.04 * * * \\
(0.00)\end{array}$ & $\begin{array}{l}-0.10^{* * *} \\
(0.00)\end{array}$ & $\begin{array}{l}0.10^{* * *} \\
(0.00)\end{array}$ & $\begin{array}{l}0.03^{* * * *} \\
(0.00)\end{array}$ & $\begin{array}{c}0.01 \\
(0.48)\end{array}$ & $\begin{array}{l}-0.02 * * * \\
(0.00)\end{array}$ \\
\hline$D A$ & $\begin{array}{l}0.07 * * * \\
(0.00)\end{array}$ & $\begin{array}{l}-0.51 \text { **** } \\
(0.00)\end{array}$ & $\begin{array}{c}0.01 \\
(0.15)\end{array}$ & $\begin{array}{l}0.04 * * * \\
(0.00)\end{array}$ & $\begin{array}{l}-0.03 * * * \\
(0.00)\end{array}$ & $\begin{array}{c}0.01 \\
(0.46)\end{array}$ & $\begin{array}{l}0.02 * * \\
(0.02)\end{array}$ & $\begin{array}{l}0.01 \\
(0.16)\end{array}$ & $\begin{array}{l}0.04^{* * * *} \\
(0.00)\end{array}$ & $\begin{array}{l}-0.03 * * * \\
(0.00)\end{array}$ \\
\hline$R_{-} E M$ & $\begin{array}{l}-0.11 * * * \\
(0.00)\end{array}$ & $\begin{array}{l}-0.54 * * * \\
(0.00)\end{array}$ & $\begin{array}{l}-0.03 * * * \\
(0.00)\end{array}$ & $\begin{array}{l}0.07 * * * \\
(0.00)\end{array}$ & $\begin{array}{l}0.24 * * * \\
(0.00)\end{array}$ & $\begin{array}{l}-0.19^{* * *} \\
(0.00)\end{array}$ & $\begin{array}{l}-0.21 * * * \\
(0.00)\end{array}$ & $\begin{array}{l}-0.06 * * * \\
(0.00)\end{array}$ & $\begin{array}{l}-0.30^{* * * *} \\
(0.00)\end{array}$ & $\begin{array}{l}-0.10^{* * * *} \\
(0.00)\end{array}$ \\
\hline $\mathrm{R}_{-} \mathrm{CFO}$ & $\begin{array}{l}0.07^{* * *} \\
(0.00)\end{array}$ & $\begin{array}{l}0.81 * * * \\
(0.00)\end{array}$ & $\begin{array}{l}0.04 * * * \\
(0.00)\end{array}$ & $\begin{array}{l}-0.05^{* * * *} \\
(0.00)\end{array}$ & $\begin{array}{l}-0.21 * * * \\
(0.00)\end{array}$ & $\begin{array}{l}0.20^{* * *} \\
(0.00)\end{array}$ & $\begin{array}{l}0.17^{* * *} \\
(0.00)\end{array}$ & $\begin{array}{l}0.10^{* * *} \\
(0.00)\end{array}$ & $\begin{array}{l}0.32^{* * *} \\
(0.00)\end{array}$ & $\begin{array}{l}0.07^{* * * *} \\
(0.00)\end{array}$ \\
\hline$R_{-}$PROD & & $\begin{array}{l}-0.44 * * * \\
(0.00)\end{array}$ & & $\begin{array}{l}0.06^{* * * *} \\
(0.00)\end{array}$ & & & & $\begin{array}{l}-0.07 * * * \\
(0.00)\end{array}$ & $\begin{array}{l}-0.33^{* * *} \\
(0.00)\end{array}$ & $\begin{array}{l}-0.08^{* * * *} \\
(0.00)\end{array}$ \\
\hline$R_{-} D I S X$ & & $\begin{array}{l}0.04^{* * *} \\
(0.00)\end{array}$ & & $\begin{array}{l}-0.0 \\
(0.0\end{array}$ & & & & $\begin{array}{l}-0.03 * * * \\
(0.00)\end{array}$ & $\begin{array}{l}4^{* * * *} \\
0)\end{array}$ & $\begin{array}{l}0.08^{* * *} \\
(0.00)\end{array}$ \\
\hline$S P E C L S T T_{-} A$ & 0 & $\begin{array}{c}0.01 \\
(0.49)\end{array}$ & & $\begin{array}{c}0.01 \\
(0.40)\end{array}$ & & & & $\begin{array}{l}-0.01 \\
(0.14)\end{array}$ & $\begin{array}{l}0.01 \\
(0.37)\end{array}$ & $0.15^{* * *}$ \\
\hline SPECLST_B & & $\begin{array}{l}-0.00 \\
(0.77)\end{array}$ & & & & $\begin{array}{c}0.01 \\
(0.49)\end{array}$ & & $\begin{array}{l}-0.01 \\
(0.22)\end{array}$ & & $\begin{array}{l}-0.05^{* * *} \\
(0.00)\end{array}$ \\
\hline NONSPECLST & $\begin{array}{l}-0.01 \\
(0.15)\end{array}$ & $\begin{array}{l}-0.01 \\
(0.51)\end{array}$ & $\begin{array}{l}-0.0 \\
(0.0\end{array}$ & $\begin{array}{l}-0.01 \\
(0.27)\end{array}$ & $\begin{array}{c}0.01 \\
(0.21)\end{array}$ & $\begin{array}{l}-0.02 * * \\
(0.03)\end{array}$ & $\begin{array}{l}0.02 * * \\
(0.01)\end{array}$ & $\begin{array}{c}0.01 \\
(0.11)\end{array}$ & $\begin{array}{l}-0.01 \\
(0.50)\end{array}$ & $\begin{array}{l}-0.14 * * * \\
(0.00)\end{array}$ \\
\hline SIZE & $\begin{array}{l}0.11^{* * *} \\
(0.00)\end{array}$ & $\begin{array}{l}0.10^{* * * *} \\
(0.00)\end{array}$ & $\begin{array}{l}0.12^{* * *} \\
(0.00)\end{array}$ & $\begin{array}{l}0.25^{* * *} \\
(0.00)\end{array}$ & $\begin{array}{l}0.29 * * * \\
(0.00)\end{array}$ & $\begin{array}{l}0.83^{* * *} \\
(0.00)\end{array}$ & $\begin{array}{l}-0.07^{* * *} \\
(0.00)\end{array}$ & $\begin{array}{l}0.03 * * * \\
(0.00)\end{array}$ & $\begin{array}{l}0.12^{* * *} \\
(0.00)\end{array}$ & $\begin{array}{l}0.10^{* * * *} \\
(0.00)\end{array}$ \\
\hline GROWTH & 1.00 & $\begin{array}{l}0.14 * * * \\
(0.00)\end{array}$ & $\begin{array}{l}-0.03^{* * *} \\
(0.00)\end{array}$ & $\begin{array}{l}-0.06^{* * * *} \\
(0.00)\end{array}$ & $\begin{array}{l}0.04 * * * \\
(0.00)\end{array}$ & $\begin{array}{l}0.13 * * * \\
(0.00)\end{array}$ & $\begin{array}{l}0.20^{* * *} \\
(0.00)\end{array}$ & $\begin{array}{l}0.11^{* * *} \\
(0.00)\end{array}$ & $\begin{array}{l}0.15^{* * *} \\
(0.00)\end{array}$ & $\begin{array}{l}0.03^{* * * *} \\
(0.00)\end{array}$ \\
\hline CFO & $\begin{array}{l}0.02 * * * \\
(0.01)\end{array}$ & 1.00 & $\begin{array}{l}0.04 * * * \\
(0.00)\end{array}$ & $\begin{array}{l}-0.11 * * * \\
(0.00)\end{array}$ & $\begin{array}{l}-0.18^{* * *} \\
(0.00)\end{array}$ & $\begin{array}{l}0.25^{* * *} \\
(0.00)\end{array}$ & $\begin{array}{l}0.24 * * * \\
(0.00)\end{array}$ & $\begin{array}{l}0.11 * * * \\
(0.00)\end{array}$ & $\begin{array}{l}0.44^{* * *} \\
(0.00)\end{array}$ & $\begin{array}{l}0.12 * * * \\
(0.00)\end{array}$ \\
\hline TENURE & $\begin{array}{l}-0.05^{* * *} \\
(0.00)\end{array}$ & $\begin{array}{l}0.04 * * * \\
(0.00)\end{array}$ & 1.00 & $\begin{array}{l}0.13^{* * * *} \\
(0.00)\end{array}$ & $\begin{array}{l}-0.04 * * * \\
(0.00)\end{array}$ & $\begin{array}{l}0.11^{* * *} \\
(0.00)\end{array}$ & $\begin{array}{l}-0.05^{* * *} \\
(0.00)\end{array}$ & $\begin{array}{l}-0.01 \\
(0.11)\end{array}$ & $\begin{array}{l}4 * * * \\
\text { b) }\end{array}$ & $\begin{array}{l}-0.03 * * * \\
(0.00)\end{array}$ \\
\hline$A G E$ & $\begin{array}{l}-0.04 * * * * \\
(0.00)\end{array}$ & $\begin{array}{l}-0.08^{* * * *} \\
(0.00)\end{array}$ & $\begin{array}{l}0.15^{* * *} \\
(0.00)\end{array}$ & 1.00 & $\begin{array}{l}0.12^{* * *} \\
(0.00)\end{array}$ & $\begin{array}{l}0.10^{* * *} \\
(0.00)\end{array}$ & $\begin{array}{l}-0.27 * * * \\
(0.00)\end{array}$ & $\begin{array}{l}-0.02 * * \\
(0.03)\end{array}$ & $\begin{array}{l}-0.14 * * * \\
(0.00)\end{array}$ & $\begin{array}{l}-0.17 * * * \\
(0.00)\end{array}$ \\
\hline$L E V$ & $0.05^{* * *}$ & $-0.16^{* * * *}$ & $-0.03^{* * *}$ & $0.11 * * *$ & 1.00 & -0.01 & $-0.13^{* * *}$ & -0.00 & $-0.28^{* * *}$ & $-0.04 * * *$ \\
\hline$L N M A R$ & $\begin{array}{l}0.02^{* * *} \\
(0.00)\end{array}$ & $\begin{array}{l}0.24 * * * \\
(0.00)\end{array}$ & $\begin{array}{l}0.10^{* * *} \\
(0.00)\end{array}$ & $\begin{array}{l}0.12^{* * * *} \\
(0.00)\end{array}$ & $\begin{array}{l}-0.01 * \\
(0.07)\end{array}$ & 1.00 & $\begin{array}{l}0.38^{* * *} \\
(0.00)\end{array}$ & $\begin{array}{l}0.14 * * * \\
(0.00)\end{array}$ & $\begin{array}{l}0.41^{* * *} \\
(0.00)\end{array}$ & $\begin{array}{l}0.16^{* * * *} \\
(0.00)\end{array}$ \\
\hline MTB & $\begin{array}{l}0.13^{* * *} \\
(0.00)\end{array}$ & $\begin{array}{l}0.20^{* * * *} \\
(0.00)\end{array}$ & $\begin{array}{l}-0.06^{* * * *} \\
(0.00)\end{array}$ & $\begin{array}{l}-0.24 * * * \\
(0.00)\end{array}$ & $\begin{array}{l}-0.09 * * * \\
(0.00)\end{array}$ & $\begin{array}{l}0.34 * * * \\
(0.00)\end{array}$ & 1.00 & $\begin{array}{l}0.26 * * * \\
(0.00)\end{array}$ & $\begin{array}{l}0.55^{* * *} \\
(0.00)\end{array}$ & $\begin{array}{l}0.10^{* * * *} \\
(0.00)\end{array}$ \\
\hline$\Delta E$ & $\begin{array}{l}0.07^{* * * *} \\
(0.00)\end{array}$ & $\begin{array}{l}0.07 * * * \\
(0.00)\end{array}$ & $\begin{array}{l}-0.03^{* * *} \\
(0.00)\end{array}$ & $\begin{array}{l}-0.03 * * * \\
(0.00)\end{array}$ & $\begin{array}{l}-0.00 \\
(0.72)\end{array}$ & $\begin{array}{l}0.08^{* * * *} \\
(0.00)\end{array}$ & $\begin{array}{l}0.27^{* * *} \\
(0.00)\end{array}$ & 1.00 & $\begin{array}{l}0.43^{* * *} \\
(0.00)\end{array}$ & $\begin{array}{l}0.01 \\
(0.43)\end{array}$ \\
\hline $\mathrm{ROA}$ & $\begin{array}{l}0.01 \\
(0.49)\end{array}$ & $\begin{array}{l}0.41 * * * \\
(0.00)\end{array}$ & $\begin{array}{l}0.03^{* * *} \\
(0.00)\end{array}$ & $\begin{array}{l}-0.11^{* * * *} \\
(0.00)\end{array}$ & $\begin{array}{l}-0.267^{* *} \\
(0.00)\end{array}$ & $\begin{array}{l}0.38^{* * *} \\
(0.00)\end{array}$ & $\begin{array}{l}0.44^{* * *} \\
(0.00)\end{array}$ & $\begin{array}{l}0.45^{* * *} \\
(0.00)\end{array}$ & 1.00 & $\begin{array}{l}0.11^{* * * *} \\
(0.00)\end{array}$ \\
\hline BIGN & $\begin{array}{l}-0.04 * * * \\
(0.00)\end{array}$ & $\begin{array}{l}0.12 * * * \\
(0.00)\end{array}$ & $\begin{array}{l}-0.07^{* * * *} \\
(0.00)\end{array}$ & $\begin{array}{l}-0.16^{* * * *} \\
(0.00)\end{array}$ & $\begin{array}{l}-0.05^{* * *} \\
(0.00)\end{array}$ & $\begin{array}{l}0.17^{* * *} \\
(0.00)\end{array}$ & $\begin{array}{l}0.07^{* * *} \\
(0.00)\end{array}$ & $\begin{array}{l}-0.01 \\
(0.33)\end{array}$ & $\begin{array}{l}0.11^{* * *} \\
(0.00)\end{array}$ & 1.00 \\
\hline
\end{tabular}


Table 4

Audit Quality, Tenure and Accrual Earnings Management

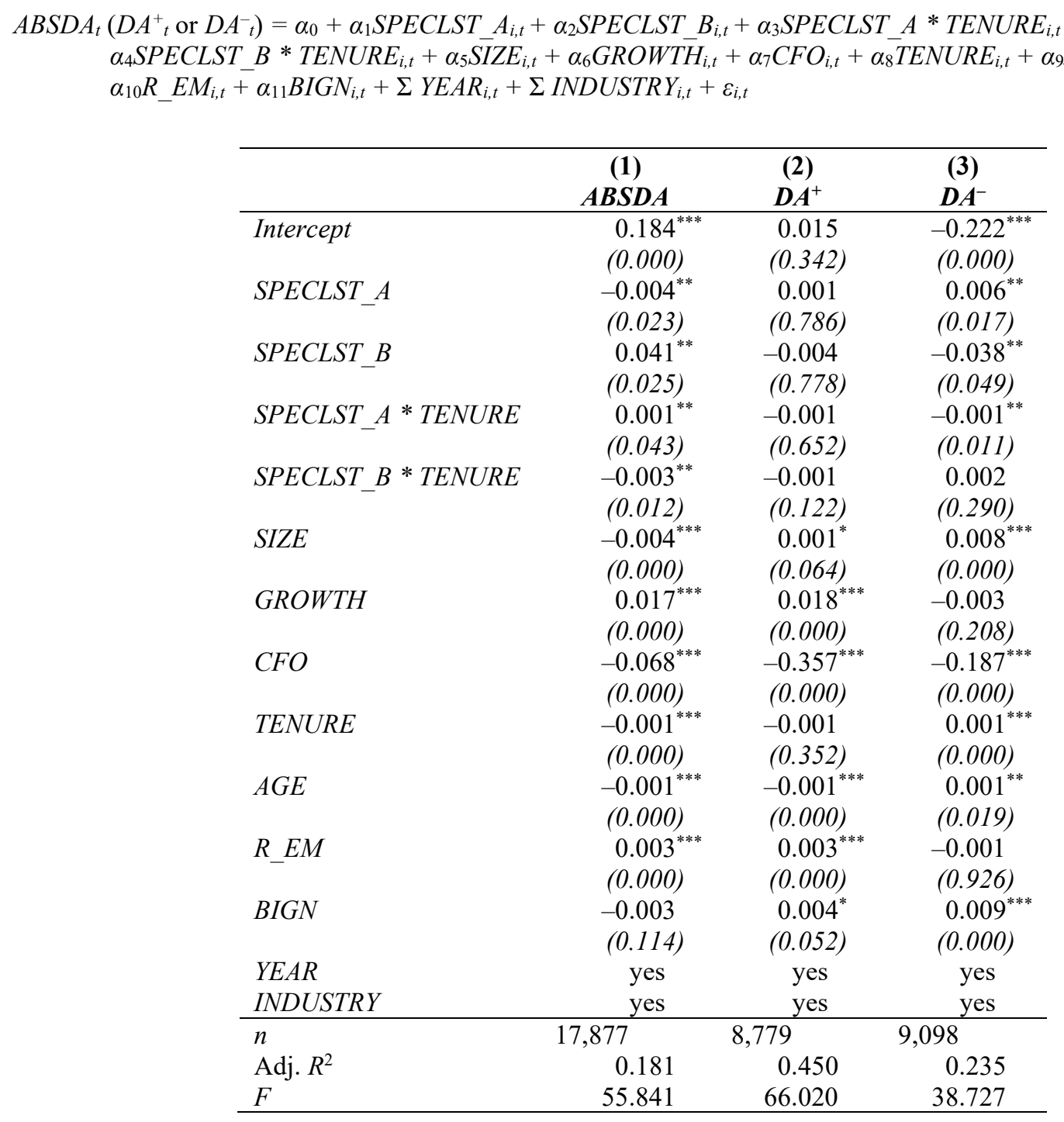

Note:

a. Numbers in parentheses represent $p$-values. Coefficients on industry and year dummies omitted for simplicity.

b. ${ }^{* * *},{ }^{* *},{ }^{*}$ indicate significance at the $1 \%, 5 \%$ and $10 \%$ level, respectively (two-tailed). We used two-way clusterrobust standard errors (clustered by firm and by year) to adjust for both cross-sectional and time-series dependence in our data (Petersen, 2009; Gow, Ormazabal and Taylor, 2010).

c. Variables are as defined in Table 2. 
Table 5

Audit Quality, Tenure and Real Earnings Management

$R \_E M_{t},\left(R \_C F O_{t}\right.$ or $R \_P R O D_{t}$ or $\left.R \_D I S X_{t}\right)=\gamma_{0}+\gamma_{1} S P E C L S T \_A_{t}+\gamma_{2} S P E C L S T \_B_{t}+\gamma_{3} S P E C L S T \_A * T E N U R E_{t}+$ $\gamma_{4}$ SPECLST_B $*$ TENURE $E_{t}+\gamma_{5} L E V_{t}+\gamma_{6} L N M A R_{t}+\gamma_{7} M T B_{t}+\gamma_{8} \Delta E_{t}+\bar{\gamma}_{9} R O A_{t}+\gamma_{10} A B S D A_{t}+\gamma_{11} B I G N_{t}+$ $\Sigma Y E A R+\Sigma$ INDUSTRY $+\varepsilon_{t}$

\begin{tabular}{|c|c|c|c|c|}
\hline & $\begin{array}{c}\text { (1) } \\
R \_E M\end{array}$ & $\begin{array}{c}(2) \\
R \_C F O\end{array}$ & $\begin{array}{l}\text { (3) } \\
\text { R_PROD }\end{array}$ & $\begin{array}{l}(4) \\
R \_I S X\end{array}$ \\
\hline \multirow[t]{2}{*}{ Intercept } & 0.607 & $-0.074^{* *}$ & -0.074 & -0.046 \\
\hline & $(0.351)$ & $(0.034)$ & $(0.103)$ & $(0.243)$ \\
\hline \multirow[t]{2}{*}{ SPECLST_A } & $0.127^{*}$ & -0.001 & 0.008 & $-0.009^{* *}$ \\
\hline & $(0.065)$ & $(0.845)$ & $(0.118)$ & $(0.013)$ \\
\hline \multirow[t]{2}{*}{ SPECLST_B } & -0.272 & $0.079^{* * *}$ & -0.002 & -0.025 \\
\hline & $(0.487)$ & $(0.000)$ & $(0.952)$ & $(0.245)$ \\
\hline \multirow[t]{2}{*}{ SPECLST_A $*$ TENURE } & -0.006 & -0.001 & -0.001 & 0.001 \\
\hline & $(0.455)$ & $(0.904)$ & $(0.431)$ & $(0.364)$ \\
\hline \multirow[t]{2}{*}{ SPECLST_B * TENURE } & 0.010 & $-0.004^{* * *}$ & -0.001 & 0.001 \\
\hline & $(0.675)$ & $(0.000)$ & $(0.775)$ & $(0.348)$ \\
\hline \multirow[t]{2}{*}{ TENURE } & -0.003 & 0.001 & -0.001 & -0.001 \\
\hline & $(0.562)$ & $(0.393)$ & $(0.396)$ & $(0.984)$ \\
\hline \multirow[t]{2}{*}{$L E V$} & $1.569^{* * *}$ & $-0.072^{* * *}$ & $0.104^{* * *}$ & $-0.066^{* * *}$ \\
\hline & $(0.000)$ & $(0.000)$ & $(0.000)$ & $(0.000)$ \\
\hline \multirow[t]{2}{*}{$L N M A R$} & -0.042 & $0.005^{* * *}$ & 0.002 & $0.003^{*}$ \\
\hline & $(0.102)$ & $(0.000)$ & $(0.260)$ & $(0.055)$ \\
\hline \multirow[t]{2}{*}{$M T B$} & $-0.220^{* * *}$ & $0.006^{* * *}$ & $-0.019^{* * *}$ & $0.009^{* * *}$ \\
\hline & $(0.000)$ & $(0.000)$ & $(0.000)$ & $(0.000)$ \\
\hline \multirow[t]{2}{*}{$\Delta E$} & $1.800^{* * *}$ & $-0.067^{* * *}$ & $0.157^{* * *}$ & $-0.059^{* * *}$ \\
\hline & $(0.000)$ & $(0.002)$ & $(0.000)$ & $(0.000)$ \\
\hline \multirow[t]{2}{*}{$R O A$} & $-3.111^{* * *}$ & $0.270^{* * *}$ & $-0.326^{* * *}$ & $-0.048^{* *}$ \\
\hline & $(0.000)$ & $(0.000)$ & $(0.000)$ & $(0.023)$ \\
\hline \multirow[t]{2}{*}{$A B S D A$} & $3.527^{* * *}$ & $-0.247^{* * *}$ & $0.270^{* * *}$ & $-0.060^{* * *}$ \\
\hline & $(0.000)$ & $(0.000)$ & $(0.000)$ & $(0.001)$ \\
\hline \multirow[t]{2}{*}{$B I G N$} & $-0.251^{* * *}$ & $0.006^{*}$ & $-0.015^{* * *}$ & $0.015^{* * *}$ \\
\hline & $(0.001)$ & $(0.058)$ & $(0.005)$ & $(0.002)$ \\
\hline$Y E A R$ & yes & yes & yes & yes \\
\hline INDUSTRY & yes & yes & yes & yes \\
\hline$n$ & 17,877 & 17,877 & 17,877 & 17,877 \\
\hline Adj. $R^{2}$ & 0.158 & 0.150 & 0.162 & 0.055 \\
\hline$F$ & 50.931 & 40.116 & 49.412 & 18.667 \\
\hline
\end{tabular}

Note:

a. Numbers in parentheses represent $p$-values. Coefficients on industry and year dummies omitted for simplicity.

b. ${ }^{* * *},{ }^{* *},{ }^{*}$ indicate significance at the $1 \%, 5 \%$ and $10 \%$ level, respectively (two-tailed). We used the two-way clusterrobust standard errors (cluster by firm and by year) to adjust for both cross-sectional and time-series dependence in our data (Petersen, 2009; Gow et al., 2010).

c. Variables are as defined in Table 2. 
Table 6

\section{Additional Analyses}

\begin{tabular}{|c|c|c|c|}
\hline & (1) & (2) & (3) \\
\hline & $A B S D A$ & $D A^{+}$ & $D A^{-}$ \\
\hline \multirow[t]{2}{*}{ Intercept } & $0.173^{* * *}$ & 0.027 & $-0.209^{* * *}$ \\
\hline & $(0.000)$ & $(0.341)$ & $(0.000)$ \\
\hline \multirow[t]{2}{*}{$I N D \_E X P$} & $-0.047^{* *}$ & -0.004 & $0.041^{* *}$ \\
\hline & $(0.015)$ & $(0.822)$ & (0.019) \\
\hline \multirow[t]{2}{*}{ IND_EXP * TENURE } & $0.004^{* * *}$ & 0.002 & -0.002 \\
\hline & $(0.008)$ & $(0.102)$ & $(0.165)$ \\
\hline \multirow[t]{2}{*}{ SIZE } & $-0.003^{* * *}$ & 0.001 & $0.007^{* * *}$ \\
\hline & $(0.000)$ & $(0.226)$ & $(0.000)$ \\
\hline \multirow[t]{2}{*}{ GROWTH } & $0.018^{* * *}$ & $0.018^{* * *}$ & 0.001 \\
\hline & $(0.000)$ & $(0.000)$ & $(0.868)$ \\
\hline \multirow[t]{2}{*}{$\mathrm{CFO}$} & $-0.060^{* * *}$ & $-0.349^{* * *}$ & $-0.203^{* * *}$ \\
\hline & $(0.000)$ & $(0.000)$ & $(0.000)$ \\
\hline \multirow[t]{2}{*}{ TENURE } & $-0.004^{* * *}$ & $-0.002^{* *}$ & $0.003^{*}$ \\
\hline & $(0.005)$ & $(0.046)$ & (0.094) \\
\hline \multirow[t]{2}{*}{$A G E$} & $-0.001^{* * *}$ & $-0.001^{* * *}$ & 0.001 \\
\hline & $(0.000)$ & $(0.004)$ & $(0.248)$ \\
\hline \multirow[t]{2}{*}{$R \_E M$} & $0.003^{* * *}$ & $0.003^{* * *}$ & 0.001 \\
\hline & $(0.001)$ & $(0.004)$ & $(0.965)$ \\
\hline \multirow[t]{2}{*}{$B I G N$} & 0.004 & $0.007^{* *}$ & 0.003 \\
\hline & $(0.286)$ & (0.049) & $(0.564)$ \\
\hline Industry & yes & yes & yes \\
\hline Year & yes & yes & yes \\
\hline$n$ & 5,011 & 2,470 & 2,541 \\
\hline Adj. $R^{2}$ & 0.193 & 0.443 & 0.252 \\
\hline$F$ & 23.532 & 23.140 & 15.650 \\
\hline
\end{tabular}

\section{Note:}

a. Numbers in parentheses represent $p$-values. Coefficients on industry and year dummies omitted for simplicity.

b. ${ }^{* * *},{ }^{* *},{ }^{*}$ indicate significance at the $1 \%, 5 \%$ and $10 \%$ level, respectively (two-tailed). We used the two-way clusterrobust standard errors (cluster by firm and by year) to adjust for both cross-sectional and time-series dependence in our data (Petersen, 2009; Gow et al., 2010).

c. Variables are as defined in Table 2.

d. $I N D_{-} E X P=1$ if the auditor belongs to $S P E C L S T \_A$, and $=0$ if the auditor belongs to SPECLST_B.

e. IND_EXP * TENURE is an interaction variable for auditor industry specialist and auditor tenure. 
Table 7

Additional Analyses

$R \_E M_{t},\left(R \_C F O_{t}\right.$ or $R \_P R O D_{t}$ or $\left.R \_D I S X_{t}\right)=\gamma_{0}+\gamma_{1} I N D \_E X P_{t}+\gamma_{2} I N D \_E X P * T E N U R E_{t}+\gamma_{3} T E N U R E_{t}+$ $\gamma_{4} \bar{L} E V_{t}+\gamma_{5} L \bar{N} M A R_{t}+\gamma_{6} \overline{M T} B_{t}+\gamma_{7} \Delta E_{t}+\gamma_{8} R O \overline{A_{t}}+\gamma_{9} A B S D A_{t}+\gamma_{10} B I G N_{t}+\Sigma Y E A R+\Sigma I N D U S T R Y+\varepsilon_{t}$

\begin{tabular}{|c|c|c|c|c|}
\hline & $\begin{array}{c}(1) \\
R_{-} E M\end{array}$ & $\begin{array}{c}(2) \\
R_{-} C F O\end{array}$ & $\begin{array}{c}(3) \\
R \_P R O D\end{array}$ & $\begin{array}{c}(4) \\
R_{-} D I S X\end{array}$ \\
\hline \multirow[t]{2}{*}{ Intercept } & 0.716 & -0.031 & -0.045 & -0.070 \\
\hline & $(0.401)$ & $(0.433)$ & $(0.507)$ & $(0.153)$ \\
\hline \multirow[t]{2}{*}{$I N D \_E X P$} & 0.344 & $-0.069^{* * *}$ & 0.007 & 0.012 \\
\hline & $(0.362)$ & $(0.000)$ & $(0.853)$ & $(0.552)$ \\
\hline \multirow[t]{2}{*}{ IND_EXP * TENURE } & -0.013 & $0.003^{* *}$ & 0.001 & -0.001 \\
\hline & $(0.629)$ & $(0.019)$ & $(0.917)$ & $(0.810)$ \\
\hline \multirow[t]{2}{*}{ TENURE } & 0.005 & $-0.003^{* *}$ & -0.001 & 0.001 \\
\hline & $(0.835)$ & $(0.019)$ & $(0.703)$ & $(0.535)$ \\
\hline \multirow[t]{2}{*}{$L E V$} & $1.653^{* * *}$ & $-0.066^{* * *}$ & $0.111^{* * *}$ & $-0.075^{* * *}$ \\
\hline & $(0.000)$ & $(0.000)$ & $(0.000)$ & $(0.000)$ \\
\hline \multirow[t]{2}{*}{ LNMAR } & $-0.059^{*}$ & $0.006^{* * *}$ & 0.001 & $0.003^{*}$ \\
\hline & $(0.071)$ & $(0.000)$ & $(0.798)$ & $(0.096)$ \\
\hline \multirow[t]{2}{*}{$M T B$} & $-0.181^{* * *}$ & 0.003 & $-0.017^{* * *}$ & $0.008^{* * *}$ \\
\hline & $(0.000)$ & $(0.161)$ & $(0.000)$ & $(0.000)$ \\
\hline \multirow[t]{2}{*}{$\Delta E$} & $2.243^{* * *}$ & $-0.108^{* * *}$ & $0.217^{* * *}$ & $-0.041^{*}$ \\
\hline & $(0.000)$ & $(0.003)$ & $(0.000)$ & $(0.075)$ \\
\hline \multirow[t]{2}{*}{$R O A$} & $-3.368^{* * *}$ & $0.320^{* * *}$ & $-0.326^{* * *}$ & $-0.053^{*}$ \\
\hline & $(0.000)$ & $(0.000)$ & $(0.000)$ & $(0.067)$ \\
\hline \multirow[t]{2}{*}{$A B S D A$} & $3.577^{* * *}$ & $-0.242^{* * *}$ & $0.298^{* * *}$ & -0.049 \\
\hline & $(0.000)$ & $(0.000)$ & $(0.000)$ & $(0.122)$ \\
\hline \multirow[t]{2}{*}{$B I G N$} & $-0.218^{*}$ & 0.005 & -0.010 & $0.016^{* *}$ \\
\hline & $(0.055)$ & $(0.423)$ & $(0.236)$ & $(0.037)$ \\
\hline Industry & yes & yes & yes & yes \\
\hline Year & yes & yes & yes & yes \\
\hline$n$ & 5,011 & 5,011 & 5,011 & 5,011 \\
\hline Adj. $R^{2}$ & 0.155 & 0.165 & 0.153 & 0.056 \\
\hline$F$ & 16.241 & 14.943 & 14.992 & 8.724 \\
\hline
\end{tabular}

Note:

a. Numbers in parentheses represent $p$-values. Coefficients on industry and year dummies omitted for simplicity.

b. ${ }^{* * *},{ }^{* *},{ }^{*}$ indicate significance at the $1 \%, 5 \%$ and $10 \%$ level, respectively (two-tailed). We used the two-way clusterrobust standard errors (cluster by firm and by year) to adjust for both cross-sectional and time-series dependence in our data (Petersen, 2009; Gow et al., 2010).

c. Variables are as defined in Table 2.

d. IND_EXP $=1$ if the auditor belongs to SPECLST_A and $=0$ if the auditor belongs to SPECLST_B.

e. IND_EXP * TENURE is an interaction variable for auditor industry specialist and auditor tenure. 


\section{Table 8}

\section{Additional Analyses}

\begin{tabular}{|c|c|c|c|}
\hline & (1) & $(2)$ & (3) \\
\hline & $A B S D A$ & $D A^{+}$ & $D A^{-}$ \\
\hline \multirow[t]{2}{*}{ Intercept } & $0.184^{* * *}$ & 0.031 & $-0.252^{* * *}$ \\
\hline & $(0.000)$ & $(0.128)$ & $(0.000)$ \\
\hline \multirow[t]{2}{*}{$A U D$} & $-0.004^{* *}$ & 0.001 & $0.006^{* *}$ \\
\hline & $(0.023)$ & $(0.788)$ & $(0.016)$ \\
\hline \multirow[t]{2}{*}{$A U D * T E N U R E$} & $0.001^{* *}$ & -0.001 & $-0.001^{* *}$ \\
\hline & $(0.044)$ & $(0.651)$ & $(0.011)$ \\
\hline \multirow[t]{2}{*}{ SIZE } & $-0.004^{* * *}$ & $0.001^{*}$ & $0.008^{* * *}$ \\
\hline & $(0.000)$ & $(0.065)$ & $(0.000)$ \\
\hline \multirow[t]{2}{*}{ GROWTH } & $0.017^{* * *}$ & $0.018^{* * *}$ & -0.003 \\
\hline & $(0.000)$ & $(0.000)$ & $(0.211)$ \\
\hline \multirow[t]{2}{*}{$\mathrm{CFO}$} & $-0.068^{* * *}$ & $-0.357^{* * *}$ & $-0.186^{* * *}$ \\
\hline & $(0.000)$ & $(0.000)$ & $(0.000)$ \\
\hline \multirow[t]{2}{*}{ TENURE } & $-0.001^{* * *}$ & -0.001 & $0.001^{* * *}$ \\
\hline & $(0.000)$ & $(0.353)$ & $(0.000)$ \\
\hline \multirow[t]{2}{*}{$A G E$} & $-0.001^{* * *}$ & $-0.001^{* * *}$ & $0.001^{* *}$ \\
\hline & $(0.000)$ & $(0.000)$ & $(0.019)$ \\
\hline \multirow[t]{2}{*}{$R \_E M$} & $0.003^{* * *}$ & $0.003^{* * *}$ & -0.001 \\
\hline & $(0.000)$ & $(0.000)$ & $(0.943)$ \\
\hline \multirow[t]{2}{*}{$B I G N$} & -0.003 & $0.004^{* *}$ & $0.009^{* * *}$ \\
\hline & $(0.117)$ & $(0.049)$ & $(0.000)$ \\
\hline Industry & yes & yes & Yes \\
\hline Year & yes & yes & Yes \\
\hline$n$ & 17,833 & 8,763 & 9,070 \\
\hline Adj. $R^{2}$ & 0.181 & 0.450 & 0.234 \\
\hline$F$ & 58.088 & 68.211 & 40.606 \\
\hline
\end{tabular}

Note:

a. Numbers in parentheses represent $p$-values. Coefficients on industry and year dummies omitted for simplicity.

b. ${ }^{* * *},{ }^{* *},{ }^{*}$ indicate significance at the $1 \%, 5 \%$ and $10 \%$ level, respectively (two-tailed). We used the two-way clusterrobust standard errors (cluster by firm and by year) to adjust for both cross-sectional and time-series dependence in our data (Petersen, 2009; Gow et al., 2010).

c. Variables are as defined in Table 2.

d. $A U D=1$ if the auditor is a specialist, else 0 .

e. $A U D * T E N U R E$ is an interaction variable for auditor quality and auditor tenure. 
Table 9

\section{Additional Analyses}

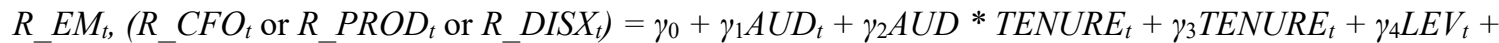
$\gamma_{5} \bar{L} M A R_{t}+\bar{\gamma}_{6} M T B_{t}+\gamma_{7} \overline{\Delta E_{t}}+\gamma_{8} R O A_{t}+\gamma_{9} A B S D A_{t}+\gamma_{10} B I G N_{t}+\Sigma Y E A R+\Sigma I N D U S T R Y+\varepsilon_{t}$

\begin{tabular}{|c|c|c|c|c|}
\hline & $\begin{array}{c}(1) \\
R_{-} E M\end{array}$ & $\begin{array}{c}(2) \\
R_{-} C F O\end{array}$ & $\begin{array}{c}(3) \\
R \_P R O D\end{array}$ & $\begin{array}{c}(4) \\
R_{-} D I S X\end{array}$ \\
\hline \multirow[t]{2}{*}{ Intercept } & 0.586 & $-0.072^{* *}$ & -0.075 & -0.046 \\
\hline & $(0.369)$ & $(0.038)$ & $(0.100)$ & $(0.248)$ \\
\hline \multirow[t]{2}{*}{$A U D$} & $0.128^{*}$ & -0.001 & 0.008 & $-0.009^{* *}$ \\
\hline & $(0.064)$ & $(0.840)$ & $(0.117)$ & $(0.013)$ \\
\hline \multirow[t]{2}{*}{$A U D * T E N U R E$} & -0.006 & -0.001 & -0.001 & 0.001 \\
\hline & $(0.454)$ & $(0.905)$ & $(0.432)$ & $(0.362)$ \\
\hline \multirow[t]{2}{*}{ TENURE } & -0.003 & 0.001 & -0.001 & -0.001 \\
\hline & $(0.565)$ & $(0.397)$ & $(0.399)$ & $(0.984)$ \\
\hline \multirow[t]{2}{*}{$L E V$} & $1.570^{* * *}$ & $-0.072^{* * *}$ & $0.103^{* * *}$ & $-0.066^{* * *}$ \\
\hline & $(0.000)$ & $(0.000)$ & $(0.000)$ & $(0.000)$ \\
\hline \multirow[t]{2}{*}{ LNMAR } & -0.041 & $0.005^{* * *}$ & 0.002 & $0.003^{*}$ \\
\hline & $(0.105)$ & $(0.000)$ & $(0.255)$ & $(0.056)$ \\
\hline \multirow[t]{2}{*}{$M T B$} & $-0.220^{* * *}$ & $0.006^{* * *}$ & $-0.019^{* * *}$ & $0.009^{* * *}$ \\
\hline & $(0.000)$ & $(0.000)$ & $(0.000)$ & $(0.000)$ \\
\hline \multirow[t]{2}{*}{$\Delta E$} & $1.799^{* * *}$ & $-0.067^{* * *}$ & $0.157^{* * *}$ & $-0.059^{* * *}$ \\
\hline & $(0.000)$ & $(0.002)$ & $(0.000)$ & $(0.000)$ \\
\hline \multirow[t]{2}{*}{$R O A$} & $-3.114^{* * *}$ & $0.270^{* * *}$ & $-0.326^{* * *}$ & $-0.048^{* *}$ \\
\hline & $(0.000)$ & $(0.000)$ & $(0.000)$ & $(0.023)$ \\
\hline \multirow[t]{2}{*}{$A B S D A$} & $3.541^{* * *}$ & $-0.248^{* * *}$ & $0.271^{* * *}$ & $-0.060^{* * *}$ \\
\hline & $(0.000)$ & $(0.000)$ & $(0.000)$ & $(0.001)$ \\
\hline \multirow[t]{2}{*}{$B I G N$} & $-0.251^{* * *}$ & $0.006^{*}$ & $-0.015^{* * *}$ & $0.016^{* * *}$ \\
\hline & $(0.001)$ & $(0.064)$ & $(0.004)$ & $(0.002)$ \\
\hline Industry & yes & yes & yes & yes \\
\hline Year & yes & yes & yes & yes \\
\hline$N$ & 17,833 & 17,833 & 17,833 & 17,833 \\
\hline adj. $R^{2}$ & 0.158 & 0.149 & 0.162 & 0.055 \\
\hline $\mathrm{F}$ & 52.670 & 41.306 & 51.123 & 19.326 \\
\hline
\end{tabular}

Note:

a. Numbers in parentheses represent $p$-values. Coefficients on industry and year dummies omitted for simplicity.

b. ${ }^{* * *},{ }^{* *},{ }^{*}$ indicate significance at the $1 \%, 5 \%$ and $10 \%$ level, respectively (two-tailed). We used the two-way clusterrobust standard errors (cluster by firm and by year) to adjust for both cross-sectional and time-series dependence in our data (Petersen, 2009; Gow et al., 2010).

c. Variables are as defined in Table 2.

d. $A U D=1$ if the auditor is a specialist, else 0 .

e. $A U D * T E N U R E$ is an interaction variable for auditor quality and auditor tenure. 